Nevada

Environmental

Restoration

Project

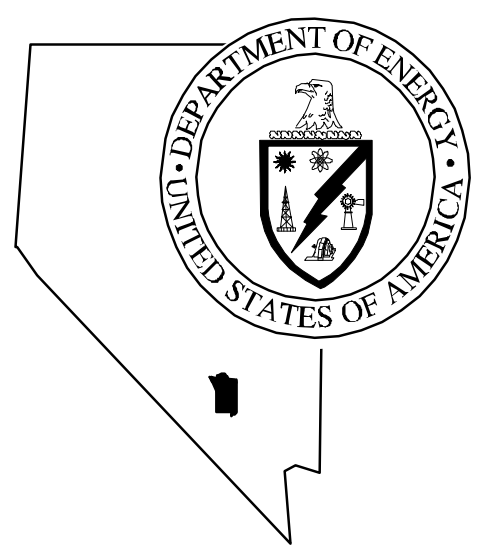

Corrective Action Investigation Plan for Corrective Action Unit 266 : Area 25 Building 3124 Leachfield, $\mathrm{N}$ evada Test Site, $\mathrm{N}$ evada

Controlled Copy N 0.:

Revision N 0.: 1

February 1999

Approved for public release; further dissemination unlimited.

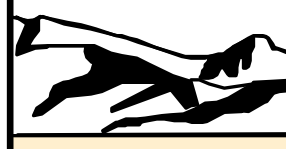

Environm ental Restoration

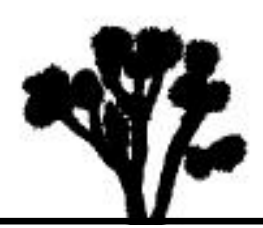

Division 
Available to the public from -

U.S. Department of Commerce

National Technical Information Service

5285 Port Royal Road

Springfield, VA 22161

(703) 487-4650

Available electronically at http://www.doe.gov/bridge. Available to U.S. Department of Energy and its contractors in paper from -

U.S. Department of Energy

Office of Scientific and Technical Information

P.O. Box 62

Oak Ridge, TN 37831-0062

(423) 576-8401

Reference herein to any specific commercial product, process, or service by trade name, trademark, manufacturer, or otherwise, does not necessarily constitute or imply its endorsement, recommendation, or favoring by the United States Government or any agency thereof or its contractors or subcontractors 


\title{
CORRECTIVE ACTION INVESTIGATION PLAN FOR CORRECTIVE ACTION UNIT 266: AREA 25 BUILDING 3124 LEACHFIELD, NEVADA TEST SITE, NEVADA
}

\author{
DOE Nevada Operations Office \\ Las Vegas, Nevada
}

Controlled Copy No.:

Revision No.: 1

February 1999

Approved for public release; further dissemination unlimited. 


\section{CORRECTIVE ACTION INVESTIGATION PLAN \\ FOR CORRECTIVE ACTION UNIT 266: \\ AREA 25 BUILDING 3124 LEACHFIELD, NEVADA TEST SITE, NEVADA}

Approved by: $\frac{\text { Signature Approved }}{\text { Janet Appenzeller-Wing, Project Manager }} \begin{aligned} & \text { Industrial Sites Project } \\ & \text { Date: }\end{aligned}$ 2/24/99

Runore C. Wycoff, Division Director

Environmental Restoration Division 


\section{Table of Contents}

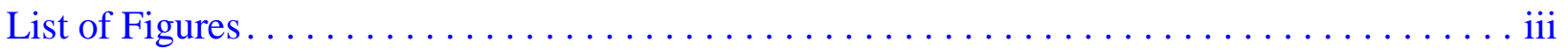

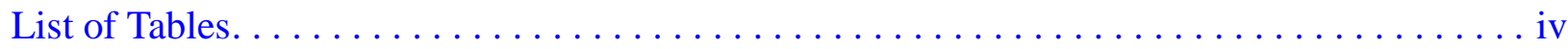

List of Acronyms and Abbreviations ............................... v

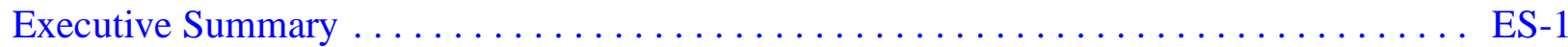

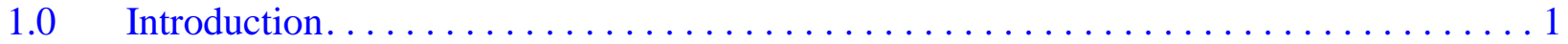

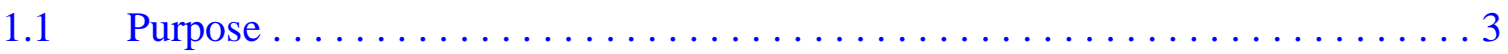

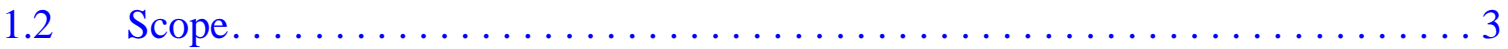

$1.3 \quad$ CAIP Contents ...................................... 4

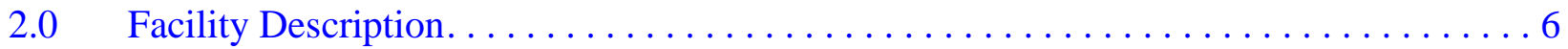

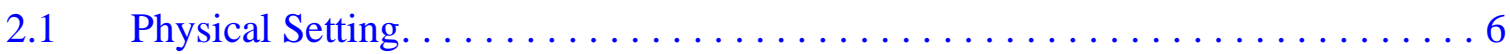

2.2 Operational History. . . . . . . . . . . . . . . . . . . . . . . . . . . 6

2.2.1 Test Cell A Support Operations ...................... 7

2.2.2 High-Level Radioactive Environmental Sample Handling

Laboratory.............................. 8

2.2.3 The Treatability Test Facility ......................... 9

2.2.4 Leachfield and Collection System $\ldots \ldots \ldots \ldots \ldots \ldots \ldots \ldots \ldots \ldots \ldots$

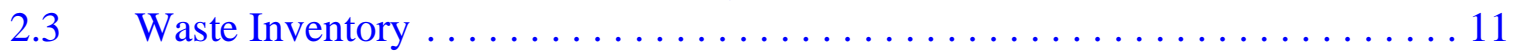

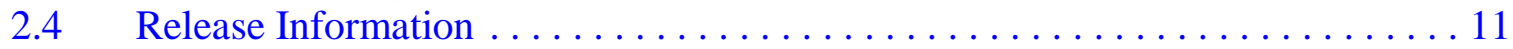

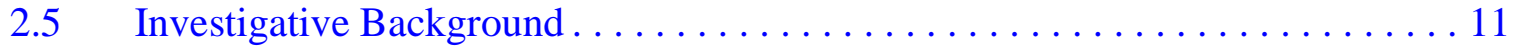

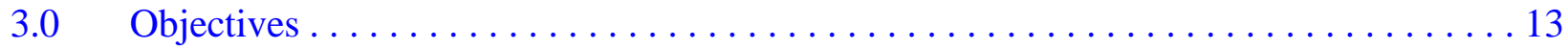

$3.1 \quad$ Conceptual Site Model ............................... 13

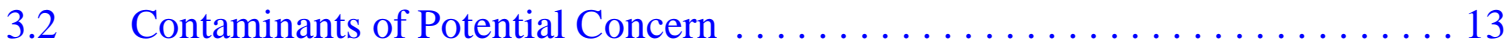

$3.3 \quad$ Preliminary Action Levels . . . . . . . . . . . . . . . . . . . . . . . . . . 14

$3.4 \quad$ DQO Process Discussion ............................... 14

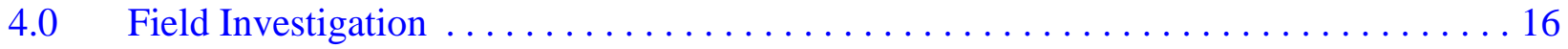

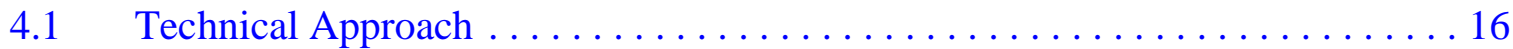

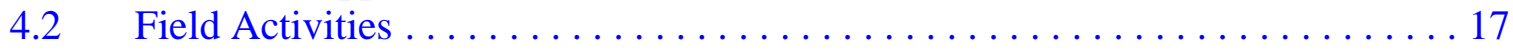

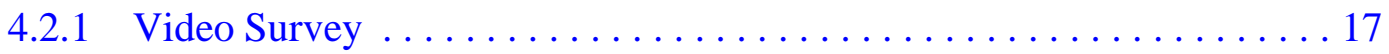

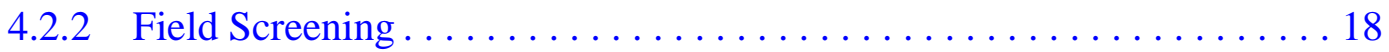

4.2.3 Leachfield System Investigation. ....................... 18

4.2.3.1 Collection System Sampling Activities . . . . . . . . . . . . 18

4.2.3.2 Leachfield Sampling Activities .................. 19

$4.3 \quad$ Second-Stage Activities . . . . . . . . . . . . . . . . . . . . . . 22 


\section{Table of Contents (Continued)}

$5.0 \quad$ Waste Management. . . . . . . . . . . . . . . . . . . . . . 23

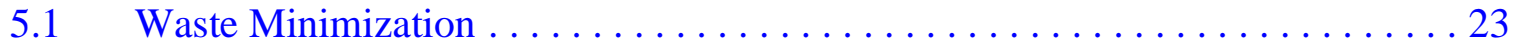

5.2 Potential Waste Streams . . . . . . . . . . . . . . . . . . . . . . 23

5.3 Investigation-Derived Waste Management $\ldots \ldots \ldots \ldots \ldots \ldots \ldots \ldots \ldots \ldots \ldots \ldots \ldots \ldots$

$6.0 \quad$ Time Frame and Records Availability ... . . . . . . . . . . . . . . . 24

$6.1 \quad$ Time Frame. . . . . . . . . . . . . . . . . . . . . . . . . . . 24

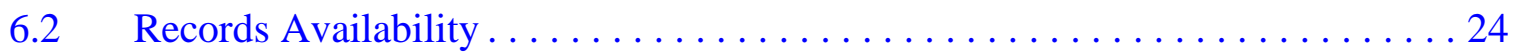

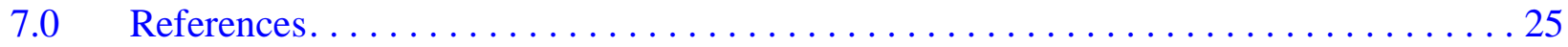

\section{Appendix A - Data Quality Objectives Worksheets}

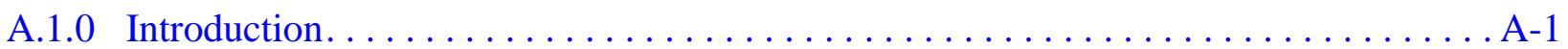

A.1.1 Problem Statement . . . . . . . . . . . . . . . . . . . . A-1

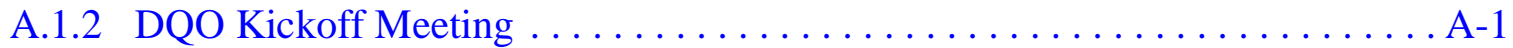

A.2.0 Conceptual Model. . . . . . . . . . . . . . . . . . . . . . . A-3

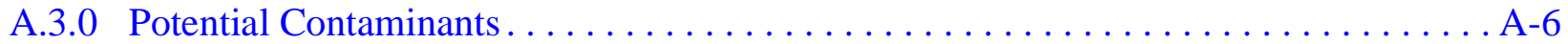

A.4.0 Decisions and Inputs. . . . . . . . . . . . . . . . . . . . . .

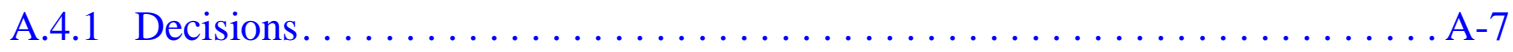

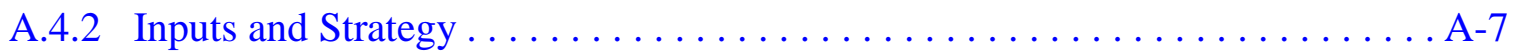

A.5.0 Investigation Strategy . . . . . . . . . . . . . . . $\ldots \ldots \ldots \ldots$

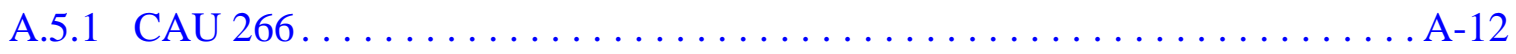

A.6.0 Decision Rules . . . . . . . . . . . . . . . . . . . . . . . . 13

A.7.0 Decision Error. . . . . . . . . . . . . . . . . . . . . . . . . A-16

A.8.0 References................................. A

Appendix B - Project Organization

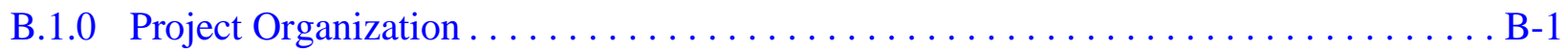

Appendix C - Building 3124 Equipment Testing Laboratory Floor Plan . . . . . . . . . . C-1

Appendix D - NDEP Document Review Sheet $\ldots \ldots \ldots \ldots \ldots \ldots \ldots \ldots \ldots \ldots \ldots \ldots$ 


\section{List of Figures}

Number

1-1 Area 25 Test Cell A Sewer Drainage and Outfalls . . . . . . . . . . . . . . 2

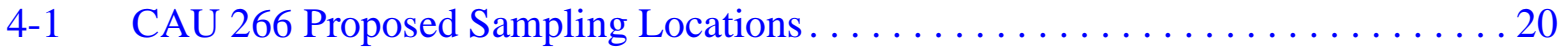

C-1 Building 3124 Equipment Testing Laboratory Floor Plan . . . . . . . . . . . C-1

C-2 Existing Water \& Sewer Layout, Test Cell "A" Plan . . . . . . . . . . . . . . . C-2

C-3 Treatability Test Facility, Building 3124 Floor Plan. . . . . . . . . . . . C-3 


\section{List of Tables}

Number

A.1-1 DQO Kickoff Meeting Participants. .................... A-2

A.2-1 Conceptual Model for the CAU 266 Leachfield System. . . . . . . . . . . . . . A-4

A.4-1 Decisions, Inputs, and General Strategies . . . . . . . . . . . . A-8

A.6-1 CAU 266 - Specific Decision Points and Rules . . . . . . . . . . . . . . . . A-14 


\section{List of Acronyms and Abbreviations}

BN Bechtel Nevada

CADD Corrective Action Decision Document

CAIP Corrective Action Investigation Plan

CAS Corrective Action Site(s)

CAU Corrective Action Unit(s)

COPC Contaminant(s) of potential concern

$\mathrm{cm} \quad$ Centimeter(s)

CR Closure Report

DOE U.S. Department of Energy

DOE/NV U.S. Department of Energy, Nevada Operations Office

DOT U.S. Department of Transportation

DQO Data Quality Objective(s)

EPA U.S. Environmental Protection Agency

ETL Equipment Testing Laboratory

FFACO Federal Facility Agreement and Consent Order

$\mathrm{ft} \quad$ Foot (feet)

HASP Health and safety plan

IDW Investigation-derived waste

in. $\operatorname{Inch}(\mathrm{es})$

km Kilometer(s)

m Meter(s)

$\mathrm{mCi} \quad$ Millicurie(s)

mi Mile(s)

NAC Nevada Administrative Code

NAEG Nevada Applied Ecology Group

NDEP Nevada Division of Environmental Protection 


\section{List of Acronyms and Abbreviations (Continued)}

NEPA National Environmental Policy Act

NRDS Nuclear Rocket Development Station

NTS Nevada Test Site

PAL Preliminary action level(s)

PCB Polychlorinated biphenyl(s)

$\mathrm{pCi} / \mathrm{g} \quad$ Picocurie(s) per gram

$\mathrm{pCi} / \mathrm{L} \quad$ Picocurie(s) per liter

PRG Preliminary Remediation Goal(s)

QAPP Quality Assurance Project Plan

QA/QC Quality assurance/quality control

RCRA Resource Conservation and Recovery Act

REECo Reynolds Electrical \& Engineering Company, Inc.

SNPO Space Nuclear Propulsion Office

SSHASP Site-specific health and safety plan

SVOC Semivolatile organic compound(s)

TPH Total petroleum hydrocarbon(s)

TTF Treatability Test Facility

VCP Vitrified clay pipe

VOC Volatile organic compound(s) 


\section{Executive Summary}

The Corrective Action Investigation Plan for Corrective Action Unit 266, Area 25 Building 3124 Leachfield, has been developed in accordance with the Federal Facility Agreement and Consent Order that was agreed to by the U.S. Department of Energy, Nevada Operations Office; the State of Nevada Division of Environmental Protection; and the U.S. Department of Defense. Corrective Action Unit 266 consists of the Corrective Action Site 25-05-09 sanitary leachfield and associated collection system.

This Corrective Action Investigation Plan is used in combination with the Work Plan for Leachfield Corrective Action Units: Nevada Test Site and Tonopah Test Range, Nevada (DOE/NV, 1998d). The Leachfield Work Plan was developed to streamline investigations at Leachfield Corrective Action Units by incorporating management, technical, quality assurance, health and safety, public involvement, field sampling, and waste management information common to a set of Corrective Action Units with similar site histories and characteristics into a single document that can be referenced. This Corrective Action Investigation Plan provides investigative details specific to Corrective Action Unit 266.

Corrective Action Unit 266 is located southwest of Building 3124 which is located southwest and adjacent to Test Cell A. Test Cell A was operational during the 1960s to test nuclear rocket reactors in support of the Nuclear Rocket Development Station. Operations within Building 3124 from 1962 through the early 1990s resulted in effluent releases to the leachfield and associated collection system. The subsurface soils in the vicinity of the collection system and leachfield may have been impacted by effluent containing contaminants of potential concern generated by support activities associated with Test Cell A reactor testing operations, various laboratories including a high-level radioactivity environmental sample handling laboratory, and possibly the Treatability Test Facility.

Based on site history collected to support the Data Quality Objectives process, contaminants of potential concern for the site include radionuclides, oil/diesel range total petroleum hydrocarbons, and Resource Conservation and Recovery Act characteristic volatile organic compounds, semivolatile organic compounds, and metals. Samples will also be analyzed for radionuclides and polychlorinated biphenyls not considered during the DQO process. Additional samples will be analyzed for geotechnical and hydrological properties and a bioassessment may be performed. A general 
conceptual site model for leachfield Corrective Action Units is developed in the Work Plan. No Corrective Action Unit-specific deviations from the model were identified during the Data Quality Objectives process for Corrective Action Unit 266.

The technical approach for investigating this Corrective Action Unit consists of the following activities:

- Perform a radiological walkover survey.

- Perform video and radiation surveys of the discharge and outfall lines.

- Collect samples from within the septic tank.

- Mark approximate locations of leachfield distribution lines on the ground surface.

- Collect subsurface soil samples in areas of the collection system including the septic tank and outfall end of the diversion chamber.

- Collect subsurface soil samples underlying the leachfield distribution pipes.

- Field screen samples for volatile organic compounds and radiological activity.

- Drill boreholes and collect subsurface soil samples if required.

- Analyze soil samples for total volatile organic compounds, total semivolatile organic compounds, total Resource Conservation and Recovery Act metals, total petroleum hydrocarbons (oil/diesel-range organics), and polychlorinated biphenyls.

- Analyze a minimum of 25 percent of the soil samples for gamma-emitting radionuclides, isotopic uranium, isotopic plutonium, isotopic americium, and strontium-90 if radiological field screening levels are exceeded.

- Collect samples from native soils beneath the distribution system and analyze for geotechnical/hydrologic parameters.

- Collect and analyze bioassessment samples at Site Supervisors discretion if volatile organic compounds exceed field-screening levels.

Additional sampling and analytical details are presented in Section 4.0 of the Corrective Action Investigation Plan and in the Leachfield Work Plan. Details of the waste management strategy for the Corrective Action Unit are included in the Leachfield Work Plan. 
Under the Federal Facility Agreement and Consent Order, the Corrective Action Investigation Plan will be submitted to the Nevada Division of Environmental Protection for approval. Field work will be conducted following approval of the plan. The results of the field investigation will support a defensible evaluation of corrective action alternatives in the Corrective Action Decision Document. 


\subsection{Introduction}

This Corrective Action Investigation Plan (CAIP) has been developed in accordance with the Federal Facility Agreement and Consent Order (FFACO) that was agreed to by the U.S. Department of Energy, Nevada Operations Office (DOE/NV); the State of Nevada Division of Environmental Protection (NDEP); and the U.S. Department of Defense (FFACO, 1996). The CAIP is a document that provides or references all of the specific information for investigation activities associated with Corrective Action Units (CAUs) or Corrective Action Sites (CASs). According to the FFACO (1996), CASs are sites potentially requiring corrective action(s) and may include solid waste management units, individual disposal sites, or release sites. Corrective Action Units consist of one or more CASs grouped together based on geography, technical similarity, or agency responsibility for the purpose of determining corrective actions.

This CAIP will be used in conjunction with the Work Plan for Leachfield Corrective Action Units: Nevada Test Site and Tonopah Test Range, Nevada (DOE/NV, 1998d), hereafter referred to as the Leachfield Work Plan. Under the FFACO, a work plan is an optional planning document that provides information for a CAU or group of CAUs where significant commonality exists. This CAIP contains CAU-specific information including a facility description, environmental sample collection objectives, and the criteria for conducting site investigation activities at CAU 266: Area 25 Building 3124 Leachfield, Nevada Test Site, Nevada.

This CAIP addresses one of three leachfield systems associated with Test Cell A, which is located in Area 25 of the Nevada Test Site (NTS). The NTS is approximately 105 kilometers $(\mathrm{km})$ (65 miles [mi]) northwest of Las Vegas, Nevada (see Leachfield Work Plan Figure 1-1). Corrective Action Unit 266 is comprised of the Area 25 Building 3124 Leachfield (CAS 25-05-09) and associated collection system shown in Figure 1-1 (FFACO, 1996).

The leachfield is located approximately 90 meters (m) (300 feet [ft]) southwest of Building 3124, which is southwest and adjacent to Test Cell A. Test Cell A was operated during the 1960s to support nuclear rocket reactor testing as part of the Nuclear Rocket Development Station (NRDS) (SNPO, 1970). Various operations within Building 3124 from 1962 through the early 1990s may have resulted in potentially hazardous or radioactive effluent releases to the leachfield system 


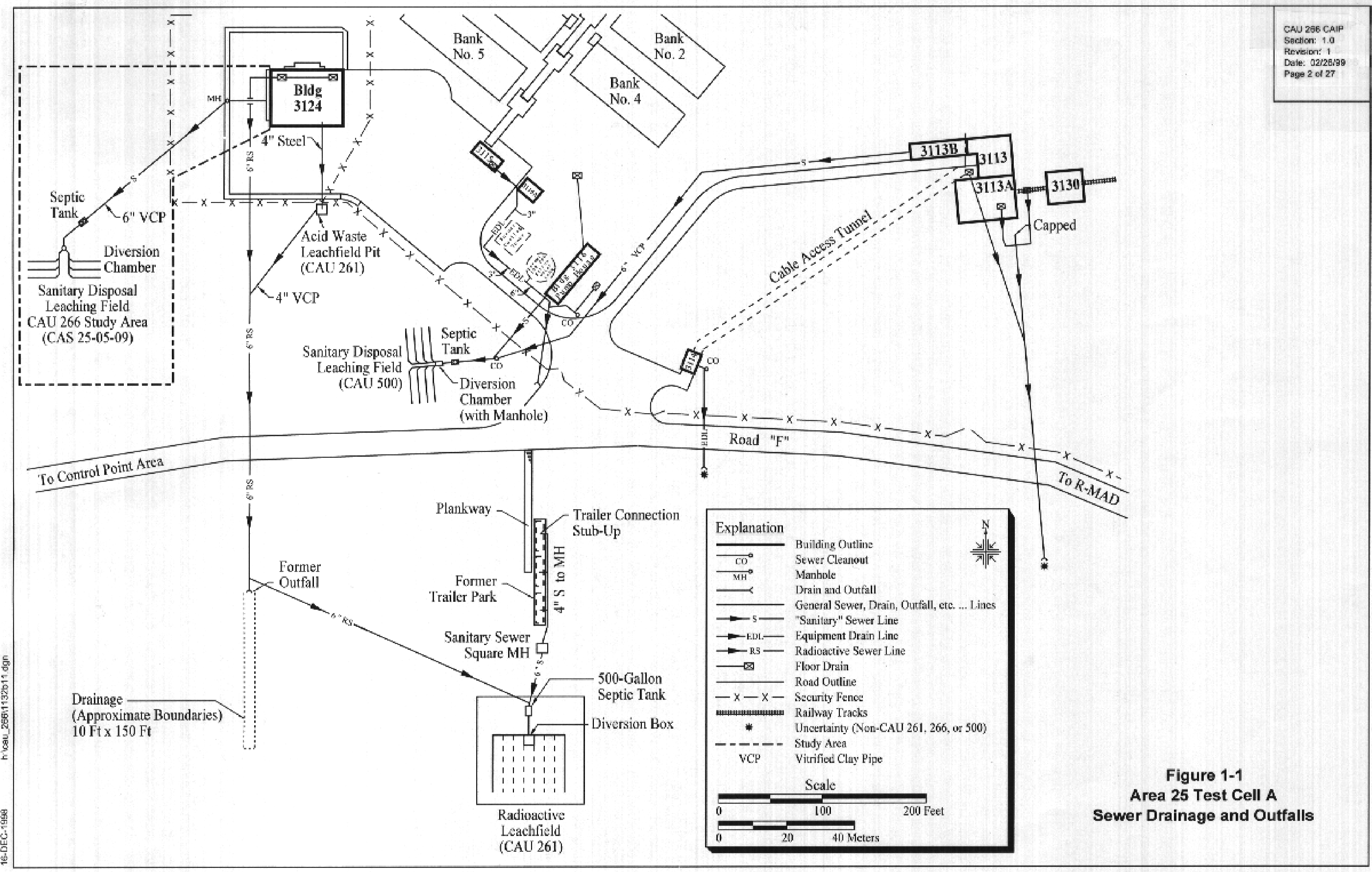


(DOE/NV, 1988a). These operations include support for Test Cell A activities, various laboratories including a high-level radioactive sample handling facility, and contaminated soil treatability experiments.

The leachfield system components include a discharge line, manway, septic tank, outfall line, diversion chamber, and a 15 by 30 m (50 by $100 \mathrm{ft}$ ) leachfield (see Leachfield Work Plan Figure 3-1 for an explanation of the terminology). In general, effluent contributed to the leachfield was sanitary wastewater associated with floor drains, toilet, and lavatory facilities within Building 3124. Hazardous or radioactive effluents produced by operations conducted in Building 3124 may have reached this leachfield via floor drains or sinks. The subsurface soils in the vicinity of the collection system and leachfield may have been impacted by effluent containing contaminants of potential concern (COPCs) generated by support activities associated with Test Cell A reactor testing operations and subsequent laboratory activities.

\subsection{Purpose}

This CAIP describes the investigation to determine the nature and extent of COPCs at CAU 266. The general purpose of corrective action investigations for leachfield CAUs is described in the Leachfield Work Plan.

\subsection{Scope}

The scope of this CAIP is to resolve the problem statement identified in the Data Quality Objective (DQO) process (see Appendix A) and assess additional information discovered after the DQO process was completed. The DQO problem statement is that sanitary and light industrial effluents may have been released at the $\mathrm{CAU}$, and that existing data are insufficient to support the development and evaluation of potential corrective actions and selection of a preferred corrective action for the CAU. Additional information indicates effluent containing hazardous or radioactive material may have been released to this leachfield in addition to the sanitary and light industrial effluents identified in the DQO process. The scope of the corrective action investigation at the CAU includes the following activities to answer the problem statement and assess additional information:

- Conducting a radiological walkover survey 
- Conducting video and radiation surveys of the discharge and outfall lines

- Conducting discrete field screening

- Sampling the contents of the septic tank

- Conducting subsurface investigations using direct push methods in the area surrounding the septic tank, diversion chamber, and in specific locations underlying the leachfield

- Collecting environmental samples for laboratory and geotechnical/hydrological analyses and waste management purposes

- Conducting subsurface sampling from soil borings, where needed, which are capable of reaching the expected vertical extent of COPCs

- Logging core recovered from soil borings to assess soil characteristics

\subsection{CAIP Contents}

Section 1.0 of this CAIP provides an introduction to this project, including the purpose and scope for this corrective action investigation. The remainder of the document details the investigation strategy. The FFACO (1996) requires that CAIPs address the following elements:

- Management

- Technical aspects

- Quality assurance

- Health and safety

- Public involvement

- Field sampling

- Waste management

The managerial aspects of this project are discussed in the DOE/NV Project Management Plan (DOE/NV, 1994) and the site-specific Field Management Plan that will be developed prior to field activities. The technical aspects of this CAIP are referenced from the Leachfield Work Plan, and contained in Section 3.0 and Section 4.0 of this document and in the DQO summary presented in Appendix A. General field and laboratory quality assurance and quality control (QA/QC) issues, including collection of QC samples, are presented in the Industrial Sites Quality Assurance Project Plan (QAPP) (DOE/NV, 1996). The health and safety aspects of this project are documented in the Environmental Restoration Project Health and Safety Plan (HASP) (DOE/NV, 1998c) and will be supplemented with a site-specific HASP (SSHASP) written prior to the start of field work. No 
CAU-specific public involvement activities are planned at this time; however, an overview of public involvement is documented in the "Public Involvement Plan" in Appendix V of the FFACO (1996). Field sampling activities are discussed in the Leachfield Work Plan and in Section 4.0 of this CAIP and waste management issues are discussed in the Leachfield Work Plan and in Section 5.0 of this CAIP. The project schedule and records availability information for this CAIP are discussed in Section 6.0 of this CAIP. Section 7.0 provides a list of project references. 


\subsection{Facility Description}

General background information pertaining to the history of the NTS and Area 25, a geologic assessment, and an overview of the area hydrogeology including depths to groundwater are provided in the Yucca Mountain Site Characterization Plan (DOE, 1988b) and Appendix A of the Leachfield Work Plan.

\subsection{Physical Setting}

The CAU is located at the Test Cell A Facility in Area 25 of the NTS, approximately $75 \mathrm{~m} \mathrm{(250} \mathrm{ft)}$ southwest of Building 3124 (see Figure 1-1).

\subsection{Operational History}

Building 3124 was constructed in 1962 to support the Test Cell A reactor test facility at the NRDS (SNPO, 1970). The building was named the Equipment Testing Laboratory (ETL). During NRDS operations, the ETL contained equipment for water flow testing, gas flow testing, static pressure testing, equipment maintenance and cleaning, and limited analytical work (Harris, undated).

Building 3124 was used for various laboratories, including a high-level radioactive sample handling facility sometime after Test Cell A was deactivated in 1966 (Perrin, 1977). This facility was probably used to support Nevada Applied Ecology Group (NAEG) sampling to examine the biological effects of plutonium and other transuranics. Activities included sample preparation and possibly some analytical work. The building was refurbished in 1991 and renamed as the Treatability Test Facility (TTF). Preparation for TTF operations included grouting the floor drains in Building 3124. The TTF was used to study radioactively contaminated soil remediation techniques for about 2.5 years. After 1995, "Waste Management" used the TTF for bench scale lead separation soil treatability tests for a short time (Finney, 1998 and Shotten, 1998). Building 3124 is currently unoccupied.

Interpretations of engineering drawings, descriptions of potential source room operations, and interviews with former NTS workers indicate the CAU 266 leachfield system received sanitary wastewaters. Activities conducted within Building 3124 may have introduced radiological material into the CAU 266 leachfield system. Interviews suggest that personnel were careful about disposal down the drains, but little information is known concerning effluent Building 3124 tenants may have 
accidently or intentionally introduced into the leachfield systems. Records of liquid waste quantities discharged through the collection systems are not available.

\subsubsection{Test Cell A Support Operations}

Operations in the ETL (Figure C-1) which generated radioactive effluent are not known. Various drains within Building 3124 channeled effluent to either a radioactive (CAU 261) or sanitary (CAU 266) leachfield system. Any radioactive effluent generated in support of Test Cell A operations would most likely have been routed to the radioactive leachfield considered as CAU 261 (DOE/NV, 1998b). The two independent systems utilized separate drains, piping, septic tanks, and leachfields. Any radionuclide contamination in the CAU 266 leachfield system is probably associated with diffuse contamination in the ETL rather than intentional disposal of radioactive effluent.

Effluent from the Flow Bay and the Cleaning Room was routed to the radioactive leachfield. Floor drains in the Static Test Bay and Equipment Room and a compressor drain were also connected to the radioactive sewer system. Effluent from the Cleaning Room was initially disposed of in the Acid Waste Leaching Pit included in CAU 261, but was subsequently routed to the CAU 261 leachfield prior to 1969 (Pan Am, 1969). It is unlikely that activities in the Flow Bay and Cleaning Room produced radiological contamination in the CAU 266 leachfield system.

The CAU 266 leachfield was installed to receive sanitary effluent from Building 3124. Floor drains located in the Control Room, Utility Room, and Toilet Room were connected to the leachfield. Additional floor drains located in the Maintenance, Assembly, and Disassembly Room also routed effluent to the CAU 266 leachfield. The hydraulic pumping unit for the Flow Bay high-pressure hydraulic system was located in the Maintenance, Assembly, and Disassembly Room. The CAU 266 leachfield received additional effluent from a toilet, urinal, and lavatory located in the Toilet Room (Holmes \& Narver, 1962). The undated Harris report regarding the ETL shows a sink located in the Clean Room (Harris, undated) that would have been connected to the CAU 266 leachfield (Holmes \& Narver, 1962). 


\subsubsection{High-Level Radioactive Environmental Sample Handling Laboratory}

Sometime after Test Cell A was deactivated in 1966, the ETL was remodeled as a laboratory. It presumably was used to handle a portion of the thousands of soil, vegetation, small and large animal tissue, filter and saltation samples collected by the NAEG as part of a study program for environmental plutonium and other transuranics in desert ecosystems. It is unknown if the Test Cell A leachfields received any effluent generated by activities conducted inside the ETL subsequent to Test Cell A support operations. It is likely that at least the sink in the former Clean Room and the toilet, urinal, and lavatory were used. The nature and disposition of effluent produced by laboratory activities within the ETL is unknown.

As late as 1975, the facility was converted to a high-level radioactivitiy environmental sample preparation and handling laboratory. This facility utilized refurbished laboratory equipment including hoods, glove boxes, and air filtration systems already present at the ETL. The high-level radioactive environmental sample handling laboratory was designed to support chemical analysis of very high radiotoxicity materials in tissue samples. A dry run designed to assess techniques, conditions, problems and precautions associated with analysis of large animal samples with millicurie (mCi) range transuranic activity was conducted in March 1975 (NAEG, 1977). Except for one or two americium-241 experiments conducted in 1979 and 1980, little documentation is available for actual transuranic sample handling conducted subsequent to the dry run.

The sample preparation facility consisted of four rooms, including a room for office space and records storage, and a room for equipment and supplies storage. The smaller of the two remaining rooms was used for "cutting" or dilution and cleanup, and the larger room was used for receiving, packaging, ashing ovens, drying ovens, a scale, freezers, and sample storage (Perrin, 1977). Work areas were monitored after each step of the procedure to check for spread of contamination by the high-level radioactive sample handling dry run (NAEG, 1976). A counting room presumably located in the ETL former control room housed equipment used to analyze air and swipe samples collected to verify contamination containment (NAEG, 1977). No spread of contamination produced by the dry run was detected (NAEG, 1976), and no documentation of contamination produced by actual operations has been identified. The laboratory included a reverse osmosis radioactive waste water cleanup system. This system utilized roughing filters, ultra filters, reverse osmosis membranes, a degasser, and a mixed resin deionizer. This facility was used by both NAEG contractors and other 
interested agencies on a short-term basis (Perrin, 1977), including radiation counting support for Area 25 decontamination and decommissioning operations conducted in the late 1970s (Miller, 1984).

The high-level radioactivity sample handling laboratory was used to process samples for plutonium and other transuranic investigations produced by several biological sampling programs. Sample preparation techniques included tissue drying, cutting, wet and dry ashing, and bone sawing. Isotopes used for these studies include cobalt-60 transuranic simulant used for a dry run of the laboratory (NAEG, 1977) and actual transuranics such as americium-241 (DOE/NV, 1982). Descriptions of at least one and possibly two sampling programs that produced samples containing americium-241 are available. Samples from an experiment conducted in the fall of 1979 were handled at the ETL. Samples from a similar experiment in the fall of 1980 are assumed to have been handled at the ETL. Swine involved in these programs were gavaged with $5.3 \mathrm{mCi}$ (first experiment) and $5.1 \mathrm{mCi}$ (second experiment) of americium-241 in a citrate form. The metabolism of the swine was monitored until they were sacrificed after hours, days, or weeks for tissue sample collection (DOE/NV, 1985). The nature and extent of additional transuranic samples handled by the high-level radioactivity laboratory are unknown.

\subsubsection{The Treatability Test Facility}

The ETL was remodeled (Figure C-3) for use as the TTF Building between 1991 and 1992 (Finney, 1998). The TTF was part of a U.S. Department of Energy (DOE) experiment conducted by a DOE contractor to study radioactively contaminated soil remediation techniques. Operations at the TTF were conducted from 1993 through 1995. The floor drains which had previously fed the leachfield were grouted prior to commencement of TTF operations and did not contribute effluent to the CAU 266 leachfield system (Finney, 1998). The sink in the former Clean Room and the toilet, urinal, and lavatory were probably used until the building was vacated.

Remains of animals used in NAEG experiments were retained in freezers at the TTF (Fiore, 1992) until the material was removed in August 1993 (REECo, 1993). Prior to removal, the material in the freezers was inadvertently allowed to thaw because electrical service was interrupted. Fluids produced by the thawed remains leaked from at least one of the freezers (Rosenberry, 1999). It is 
unlikely that these fluids reached the Test Cell A leachfields because the drains were grouted prior to the freezer leak.

\subsubsection{Leachfield and Collection System}

The CAU 266 leachfield was installed to receive effluent from Building 3124. Effluent was routed from the building to a septic tank through a discharge line under the Equipment Room on the west side of the building. The effluent flowed out of the septic tank through an outfall line into a diversion chamber and then into the leachfield itself. The leachfield is labeled as a "Sanitary Disposal Leaching Field" on the engineering drawing provided as Figure C-2 (BN, 1997).

Figure 1-1 is a composite drawing derived from archived engineering drawings. These resources are referenced as drawings 25-TC-A-C1, 400-3124-M15.A, and 400-004-C6.1 (BN, 1997). Fieldverified inspections of these drawings indicate that a 15-centimeter ( $\mathrm{cm})(6$-inch [in.]) vitrified clay pipe (VCP) discharge line received and channeled the effluent away from Building 3124

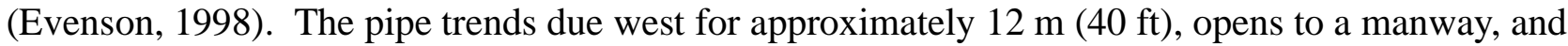
then angles southwest for $57 \mathrm{~m}(187 \mathrm{ft})$ before reaching a septic tank. The septic tank appears to be a pre-cast reinforced concrete tank as required by engineering specifications. Available drawings show a profile of the tank, but do not give a total capacity. An outfall line from the tank extends $7 \mathrm{~m}(23 \mathrm{ft})$ before reaching a diversion chamber at the mouth of the 15 by $30 \mathrm{~m}$ (50 by $100 \mathrm{ft}$ ) leachfield. Drawing Reference No. 400-004-C7.1 provides a profile of these components (BN, 1997). The diversion chamber channeled effluent into distribution manifolds and associated distribution pipes designed to disperse waste into the leachfield.

Construction specifications including the configuration and some details regarding composition and dimensions of the leachfield are provided in drawing Reference No. 400-004-C6.1 (BN, 1997). Two distribution manifolds stem from the diversion chamber in southwest and southeast directions. After approximately $9 \mathrm{~m}(30 \mathrm{ft})$, the manifolds run from north to south in parallel. It is unclear if these manifolds are sealed or are jointed or perforated to allow effluent disposal. Three 11-m (35-ft) distribution pipes branch from each manifold at right angles. The individual distribution pipes consist of jointed $10 \mathrm{~cm}$ (4-in.) wide pipe sections which are designed to allow effluent to flow into the surrounding leachrock. It is unknown if the ends of the distribution pipes are open or are capped. A 
60-cm (24-in.) wide and 56-cm (22-in.) thick leachrock bed covered with a 30-cm (12-in.) soil cap surrounds each distribution pipe. The pipe is placed in the approximate upper third of the bed.

\subsection{Waste Inventory}

Information from interviews with former NTS workers (Finney, 1998 and Shotton, 1998), interpretations of engineering drawings (BN, 1997), descriptions of processes, and a brief list of the specific uses of the rooms in Building 3124 (Harris, undated) indicate that sanitary and possibly industrial wastewaters were disposed in the collection system. Various laboratories including a high-level radioactivity environmental sample handling laboratory were present in Building 3124 (Perrin, 1977) and may have contributed effluent to the CAU 266 leachfield system. No details concerning the waste inventory within the source building during the various years of operation were identified. The quantities of wastewater generated or discharged during the operational periods is unknown (DOE, 1988a). No evidence of routine transfer practices or documentation of liquid waste disposal was revealed in the CAU 266 preliminary assessment phase.

\subsection{Release Information}

The source of potential contamination associated with the collection system is wastewater that was channeled from Building 3124 floor drains, sink, lavatory, toilet, and urinal. The effluent was routed through a single discharge line leading to an in-line septic tank, then the effluent was routed to a diversion chamber, and released into the leachfield. The leachfield was designed for liquid to be dispersed into an area within the installed leachfield material (leachrock), and to percolate down into the underlying native soil. The driving force for downward migration of the contamination was the discharge from the septic tank. The possibility of leakage at points along the collection system exists, but there is no evidence of documented leaks or releases. The leachfield system is now inactive.

\section{$2.5 \quad$ Investigative Background}

In accordance with DOE/NV National Environmental Policy Act (NEPA) compliance program, a NEPA checklist will be completed prior to commencement of site investigation activities at CAU 266. This checklist compels DOE/NV projects to evaluate their proposed project against a list of several potential environmental impacts which include, but are not limited to, air quality, chemical use, waste generation, noise level, and land use. Completion of the checklist results in a 
determination of the appropriate level of NEPA documentation by the DOE/NV NEPA Compliance Officer.

General site investigation activities are described in Section 2.0 of the Leachfield Work Plan. The U.S. Department of Energy Environment, Safety and Health, Office of Environmental Audit reviewed available historical information, collected soil samples, and prepared an environmental survey as a preliminary report in April 1988 (DOE, 1988a). No specific investigation of the CAU 266 leachfield system was conducted. A soil sampling effort at several NTS sites was performed, but analytical results for "Test Cell A Leachfield" are probably associated with the CAU 261 leachfield system rather than with this CAU (see Figure 1-1). No CAU-specific information was recovered from this source. The survey team discovered that there is very little documentation regarding the past activities at the NRDS facilities.

A Reynolds Electrical \& Engineering Company, Inc. (REECo) sampling effort recovered samples from 20 septic tank systems at the NTS during 1993 and 1994, but no samples were collected from the leachfield system addressed by this CAU (REECo, 1995). Samples were collected from CAU 500 (see Figure 1-1) during this effort, but the only results that could be applied to the CAU 266 investigation are from a "background soil" sample. 


\subsection{Objectives}

A discussion of general objectives for leachfield CAUs is presented in Section 3.0 of the Leachfield Work Plan. Objectives addressed in this CAIP are based on the Leachfield Work Plan and CAU-specific DQOs. Unless otherwise noted, objectives for CAU 266 are identical to those developed in the Leachfield Work Plan.

\subsection{Conceptual Site Model}

The conceptual model for CAU 266 is analogous to the general leachfield conceptual model presented in Section 3.1 of the Leachfield Work Plan and is described in detail in Appendix A, Table A.2-1. The scope and strategy of this investigation may be revised if the conceptual model provided in this CAIP and applicable portions of the conceptual model provided in the Leachfield Work Plan fail. The CAU 266 conceptual model may fail if substantially different historical operational information is discovered, or field observations demonstrate the nature or extent of contamination associated with the CAU is substantially different than anticipated. If necessary, a rescoping of the investigation will be conducted.

\subsection{Contaminants of Potential Concern}

Potential types of contaminants that could be present were identified through a review of site history documentation, subjective process knowledge, and inferred activities associated with the CAU. Contaminants are expected to be similar to those in septage from sanitary and light duty industrial sewage systems with the potential addition of radiological material and laboratory generated waste. Laboratory analysis of soil samples will provide the means for a quantitative measurement of the COPCs. The following analytes will be measured to determine the nature of potential contamination at CAU 266:

- Total volatile organic compounds (VOCs)

- Total semivolatile organic compounds (SVOCs)

- Total Resource Conservation and Recovery Act (RCRA) metals

- Total petroleum hydrocarbons (TPH) (oil/diesel-range organics)

- Polychlorinated biphenyls (PCBs)

- Gamma-emitting radionuclides (minimum 25 percent of samples)

- Isotopic uranium (minimum 25 percent of samples) 
- Isotopic plutonium (minimum 25 percent of samples)

- Isotopic americium (minimum 25 percent of samples)

- Strontium-90 (minimum 25 percent of samples)

The analytical methods and minimum reporting limits for each analyte are provided in Table 3-1 of the Leachfield Work Plan. Isotopic americium will be measured using analytical methods equivalent or superior to SOP 780/714 (Paragon, 1997). Minimum reporting limits for gamma-emitting radionuclides are 0.2 picocuries per gram (pCi $/ \mathrm{g}$ ) for soil and 20 picocuries per liter $(\mathrm{pCi} / \mathrm{L})$ for water (DOE/NV, 1996). Minimum reporting limits for isotopic americium are $0.05 \mathrm{pCi} / \mathrm{g}$ for soil and $0.10 \mathrm{pCi} / \mathrm{L}$ for water (Paragon, 1997). The relative percent differences and percent recoveries for isotopic americium are the same as those listed for isotopic plutonium in Table 3-1 of the Leachfield Work Plan.

Geotechnical and hydrological analysis will be performed according to the requirements of Section 3.2.1 of the Leachfield Work Plan. Bioassessment samples may be collected and analyzed according to the requirements of the Leachfield Work Plan, if field screening detects VOC concentrations greater than field screening levels.

\subsection{Preliminary Action Levels}

Screening levels for on-site field screening methods and preliminary action levels (PALs) for off-site analytical methods will be used to determine the presence of contamination. The screening levels and PALs appear in Section 3.3 of the Leachfield Work Plan and were agreed upon during the CAU-specific DQO process. For radiological constituents, PALs are the average concentrations found in an unimpacted area plus two standard deviations.

\subsection{DQO Process Discussion}

Details of the DQO process are presented in Appendix A. The DQO results for CAU 266 indicated the need for a biased sampling approach. Due to potential subsurface migration of COPCs, an investigation consisting of subsurface sampling was identified. The applicable COPCs, analytical methods, and reporting limits agreed upon during the DQO process are included in Table 3-1 of the Leachfield Work Plan and Section 3.2. Data quality will be verified and evaluated as stated in the Leachfield Work Plan. 
Significant information about various laboratories including a high-level radioactivity environmental sample handling laboratory located in Building 3124 has been discovered subsequent to completion of the DQO process and Revision 0 of this CAIP. The new information is now addressed in this CAIP. 


\subsection{Field Investigation}

The investigation activities to be performed at CAU 266 are based on general field investigation activities discussed in Section 4.0 of the Leachfield Work Plan.

\subsection{Technical Approach}

The technical approach for CAU 266 consists of the following activities:

- Perform a radiological walkover survey.

- Perform video and radiation surveys of the discharge and outfall lines.

- Collect samples from within the septic tank.

- Mark approximate locations of leachfield distribution lines on the ground surface.

- Collect subsurface soil samples in areas of the collection system including the septic tank and outfall end of the diversion chamber.

- Collect subsurface soil samples underlying the leachfield distribution pipes.

- Field screen samples for VOCs and radiological activity.

- Drill boreholes and collect subsurface soil samples if required.

- Analyze soil samples for total VOCs, total SVOCs, total RCRA metals, TPH (oil/diesel-range organics), and PCBs.

- Analyze soil samples for gamma-emitting radionuclides, isotopic uranium, isotopic plutonium, isotopic americium, and strontium-90 if radiological field screening levels are exceeded. If this percentage of samples does not meet the 25 percent minimum, then additional samples will be selected for these analyses at Site Supervisor's discretion.

- Collect samples from native soils beneath the distribution system and analyze for geotechnical/hydrologic parameters.

- Collect and analyze bioassessment samples at Site Supervisor's discretion if VOCs exceed field-screening levels. 
This investigation strategy will allow the extent of contamination associated with the leachfield system to be established. In general, the contents of the leachfield and the underlying soil will be investigated until soil samples from two consecutive intervals with contaminant concentrations below appropriate field screening levels (as stated in Section 3.3 of the Leachfield Work Plan) are obtained. If contamination is more extensive than anticipated and drilling is necessary, the maximum investigation depth will be limited by the capability of the drilling rig. If this occurs, the investigation will be rescoped.

\subsection{Field Activities}

General field activities are discussed in the Leachfield Work Plan in Section 4.1. Those field activities specific to CAU 266 are described in the following sections. All sampling activities will be conducted in compliance with the Industrial Sites QAPP (DOE/NV, 1996). Requirements for field and laboratory environmental sampling are contained in the Industrial Sites QAPP (DOE/NV, 1996) and the Leachfield Work Plan.

Excavation associated with CAU 266 will be minimized due to the potential for radiological constituents in the soil. Some excavation may be required to conduct video and radiation survey of the pipes. No excavation will be conducted within the estimated boundaries of the leachfield. Excavated soil will be stored in a manner which will prevent run-on and run-off. Soil excavated during trenching operations will be returned to the excavation as close to its original location as possible upon completion of the excavation investigation activities.

\subsubsection{Video Survey}

A video survey will be conducted inside the discharge and outfall lines to inspect the pipes associated with the collection system. The collection system will be mapped to identify potential breaches and locating or ruling out the existence of possible unknown tie-ins. This survey may not be possible for some lines because of small pipe diameters (i.e., less than 7.5-cm [3-in.] diameter), limited access, pipe damage, blockage, or other factors.

The camera and cable system will be introduced through the manhole access for the discharge line and the diversion chamber for the outfall line (Figure 1-1). Other entry points may be accessed by 
excavating at the required locations, and an excavation may be required to expose the outfall line if access through the septic tank or diversion chamber is not possible.

The video survey will evaluate the existence of unexpected contributing collection system lines from Test Cell A. If a tie-in is discovered, the line will be investigated to the source (if possible) and sampling activities will be suspended until an action consensus is reached between members of the scoping team. The discovery of an unexpected contributing line may imply an additional source input and could increase the scope of the investigation.

\subsubsection{Field Screening}

Field screening methodology is discussed in Section 4.1.3 of the Leachfield Work Plan. Field screening for VOCs and radiological activity will be performed to guide the investigation and sampling selection and to assist with health and safety and waste management decisions.

\subsubsection{Leachfield System Investigation}

The investigation of the CAU 266 leachfield system focuses on both accidental and designed effluent releases. While leachfields are designed to release effluent to the underlying soil, collection system releases are typically caused by a loss of system integrity. Potential accidental releases will be identified by sampling at specific collection system features, including soil outside the septic tank and diversion chamber. Soil underlying breached discharge and outfall lines identified during the video survey will also be sampled. The impact of designed releases will be determined by sampling the septic tank contents and soil underlying the leachfield.

\subsubsection{Collection System Sampling Activities}

A first stage of soil samples will be collected in five general areas to investigate possible release points associated with collection system components of the leachfield system. Samples will be collected from the following locations:

- Pipe disruptions identified by video survey

- Inside the septic tank

- Both ends of septic tank 
- Outfall end of diversion structure

- Both ends of distribution pipes

These locations are presented in Figure 4-1. Most samples will be collected using direct push (i.e., Geoprobe ${ }^{\circledR}$ ) methods. Samples will be collected using a drill rig if direct push methods do not provide adequate penetration or sample volumes. If results show that contaminant concentrations exceed field screening levels and/or PALs, a second stage of samples described in Section 4.3 will be collected as step-outs or at greater depths below the first stage of samples.

At least three samples will be collected from direct push locations at the septic tank and diversion chamber. Soil samples from both ends of the septic tank and the outfall end of the diversion chamber (Figure 4-1) will be collected from approximately 1.5 to $1.8 \mathrm{~m}$ (5.0 to $6.0 \mathrm{ft}$ ) below ground surface. This is the estimated depth of connecting collection system piping and components at this portion of the leachfield. Samples will also be collected from soil surrounding pipe breaks or other apparent losses of system integrity identified by the video survey. These samples will be representative of soil likely to have been impacted if leakage associated with the leachfield system occurred.

The septic tank manway is accessible at the surface and can be opened without excavation. The septic tank contents will be sampled and analyzed to determine the contents and the nature of the most recent discharge to the leachfield system. More than one sample may be required if the septic tank contents appear to have separated into multiple phases (i.e., liquid over sludge phase). The results of these samples should be representative of the effluent stream discharged to the system subsequent to the most recent septic tank pumping event. It is unknown if septage has ever been removed from this septic tank.

\subsubsection{Leachfield Sampling Activities}

The leachfield was designed for disposal of effluent after it passed through the septic tank. Soil underlying the leachfield will be sampled along four parallel transects perpendicular to the distribution pipes. Two sample collection transects parallel to the lengths of the distribution manifold and perpendicular to the lengths of the distribution pipes will be used on each side of the leachfield.

On both sides of the leachfield, the first transect will be located $1.5 \mathrm{~m}(5 \mathrm{ft})$ from the estimated location of each distribution manifold on the distribution pipe side (see Figure 4-1). Additional 


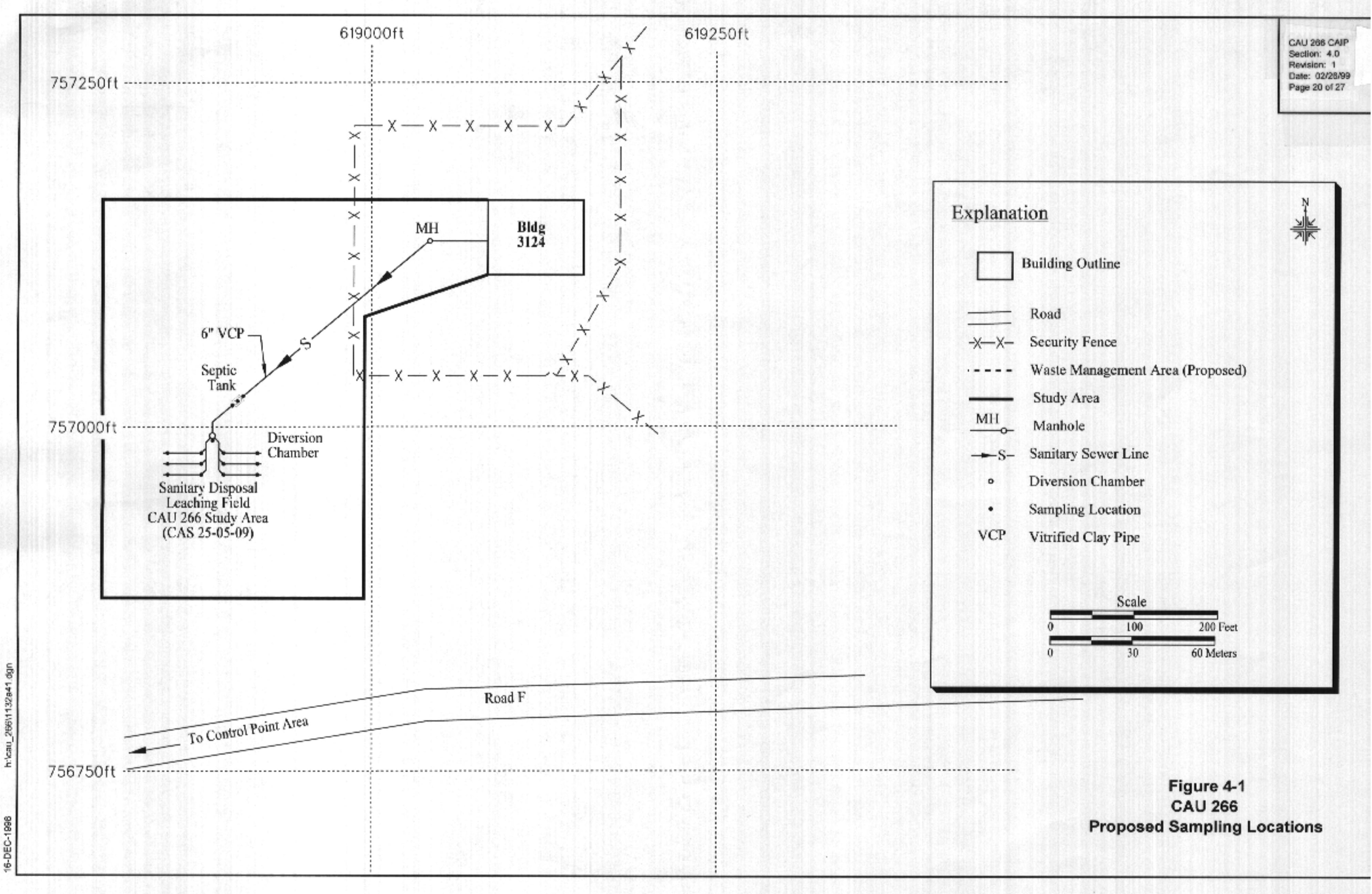


locations may be selected in an attempt to verify the location and orientation of leachfield features if these cannot be reasonably estimated based on surface features and engineering drawings. A second transect will be located approximately $1.5 \mathrm{~m}(5 \mathrm{ft})$ from the distal end of the distribution pipes based on estimated pipe lengths.

Sampling locations will be positioned below each of the six distribution pipes. Six samples per depth-interval will be collected from each side of the leachfield for a total of 12 samples per horizon. Only material (soil) suitable for sampling will be submitted to the laboratory for analysis. Leachrock will not be sampled. Additional direct push locations adjacent to planned locations may be required if extra volume for a given sampling event must be collected (i.e., duplicate samples).

An estimated depth to the leachfield base for a shallow system is 0.6 to $0.9 \mathrm{~m}$ ( 2 to $3 \mathrm{ft}$ ), and for a

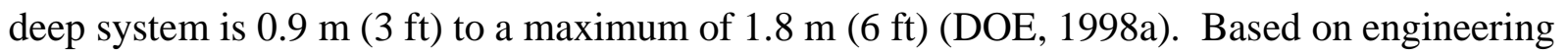

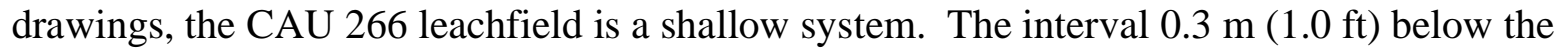
leachfield base (i.e., the leach rock and native soil interface) will define the uppermost sampling

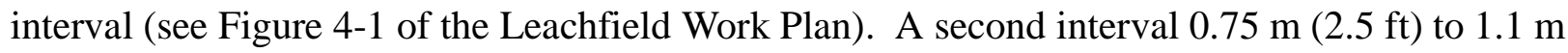
$(3.5 \mathrm{ft})$ beneath the leachfield base will also be sampled at each direct push location. If samples from a particular sampling location exceed field screening levels, a third 0.3-m (1-ft) sampling interval $2.3 \mathrm{~m}(7.5 \mathrm{ft})$ below the leachfield base may be sampled if adequate penetration can be provided by the direct push equipment.

Approximately 12 first-stage samples will be obtained from each sampling interval within the area of the leachfield based on the conceptual model. Samples will be collected from at least two sampling intervals, resulting in at least 24 samples. While all of the samples will be field screened, a limited number of these samples will be submitted to the off-site laboratory. Samples to be analyzed will be selected based on the results of field screening and minimum sampling requirements. The actual number of samples analyzed will depend on decisions made in the field.

A sample of the basement soil beneath the leachfield/soil interface will be collected to assess its geotechnical and hydrologic characteristics. In addition, bioassessment samples may be collected if VOCs are detected above field screening levels. These samples will be collected within a direct-push system liner so as not to disturb the natural physical characteristics of the soil. A split-spoon sampler 
with brass sleeves (or other, as appropriate) may be used to collect these samples if drilling is required. Section 3.2.1 of the Leachfield Work Plan addresses these analyses.

\subsection{Second-Stage Activities}

The first stage sampling results from the direct-push sampling will be used to determine if second stage samples are required. First-stage sample analytical results will be considered if they are available, but further investigation may be initiated based on field screening data. If field screening or analytical results indicate contamination extent is not defined because concentrations exceed specified field screening levels or PALs, additional sampling locations or depths will be selected to determine the contamination extent.

Additional investigation may consist of boreholes drilled within the leachfield to determine the vertical extent of contamination or step-out boreholes designed to establish lateral contamination extent as required for successful site investigation. Initial step-out boreholes will be drilled $4.6 \mathrm{~m}$ $(15 \mathrm{ft})$ outside the margins of the leachfield. Boreholes will be advanced to depths adequate to determine the vertical extent of contamination. Samples will be collected at $1.5-\mathrm{m}(5-\mathrm{ft})$ intervals beginning at the greatest depth contamination exceeding field screening levels or PALs was detected at adjacent first-stage sample locations. Sample collection will begin at the established leachfield base depth if boreholes without associated first-stage sample locations are required.

At least one confirmatory sample will be submitted from each borehole. If contamination is detected by field screening, the sample with the highest contamination concentration will be submitted. Additional samples may be submitted at the discretion of the Site Supervisor.

Alternative approaches outlining borehole placement strategies, should certain site conditions be encountered, are addressed in Section 4.1.2.1 of the Leachfield Work Plan. 


\subsection{Waste Management}

Waste management activities to be performed for CAU 266 are addressed in Section 5.0 of the Leachfield Work Plan.

\subsection{Waste Minimization}

Waste minimization activities to be performed for CAU 266 are addressed in Section 5.1 of the Leachfield Work Plan.

\subsection{Potential Waste Streams}

All potential waste types and waste streams associated with the leachfield CAUs are addressed in the Leachfield Work Plan. Based on process knowledge obtained for CAU 266, possible hazardous wastes are anticipated at this site. No process knowledge has been identified that suggests a specific "listed" hazardous waste may have been discharged to this leachfield; therefore, any RCRA regulated waste generated will likely be "characteristic." Radiological contamination may be present. Action levels for investigation-derived waste (IDW) contaminants are stated in Table 5-1 of the Leachfield Work Plan.

\subsection{Investigation-Derived Waste Management}

Investigation-derived waste will be managed according to Section 5.3 of the Leachfield Work Plan as appropriate. Investigation-derived waste which has contacted potentially contaminated media (i.e., soil, or liquid in pipes or septic tanks) will be managed as both potentially hazardous and potentially radioactive (i.e., mixed waste), according to the Leachfield Work Plan and contractor specific procedures until analytical results are received and interpreted.

Any IDW generated during this investigation will be segregated by waste stream and placed in U.S. Department of Transportation (DOT)-compliant packages appropriate for the type and amount of waste generated. The IDW generated at CAU 266 will be contained in DOT-compliant packages meeting the specifications for containers outlined in Section 5.3 of the Leachfield Work Plan. 


\subsection{Time Frame and Records Availability}

\subsection{Time Frame}

After submittal of the Final CAIP for CAU 266 to NDEP (FFACO milestone deadline of August 31,1999 ), the following is a tentative schedule of activities (in calendar days):

- Day 0: Preparation for field work will begin.

- Day 60: The field work, including field screening and sampling, will begin. Samples will be shipped to meet laboratory holding times.

- Day 110: The field work will be completed.

- Day 185: The quality-assured laboratory analytical sample data will be available for NDEP review.

- $\quad$ The FFACO date for the Corrective Action Decision Document is May 30, 2000.

\subsection{Records Availability}

Historic information and documents referenced in this plan are retained in the DOE/NV project files in Las Vegas, Nevada, and can be obtained through written request to the DOE/NV Project Manager. This document is available in the DOE public reading rooms located in Las Vegas and Carson City, Nevada, or by contacting the DOE Project Manager. The NDEP maintains the official Administrative Record for all activities conducted under the auspices of the FFACO. 


\subsection{References}

BN, see Bechtel Nevada.

Bechtel Nevada. 1997. Engineering Drawings Index Standard Report. Las Vegas, NV.

DOE, see U.S. Department of Energy.

DOE/NV, see U.S. Department of Energy, Nevada Operations Office.

Evenson, G. 1998. Field Trip to Mercury, Nevada, to perform a site walkover. Las Vegas, NV: IT Corporation.

FFACO, see Federal Facility Agreement and Consent Order.

Federal Facility Agreement and Consent Order. 1996. Agreed to by the State of Nevada, the U.S. Department of Energy, and the U.S. Department of Defense.

Finney, D., Bechtel Nevada. 1998. Personal communication to Dave Dahl, IT Corporation, regarding activities at the ETL/TTF, 12 February. Las Vegas, NV.

Fiore, J.N., U.S. Department of Energy, Nevada Field Office. 1992. Letter to Howard W. Dickson, Deputy General Manager Environmental, Safety, \& Health Division, Reynolds Electrical \& Engineering Co., Inc., regarding "Disposal of Stored Experimental Material." Las Vegas, NV.

Harris, D.L. No Date. Undated, Unlabeled Booklet Regarding the ETL (Building 3124), NRDS, introduction by D. L. Harris. Las Vegas, NV.

Holmes \& Narver, Inc. 1962. Engineering Drawing entitled, "Equipment Test \& Maintenance Lab. Modification of Utility Piping Plan, Building 3124, Area 400," Drawing No. 400-3124-M17. Mercury, NV: Bechtel Nevada Archives \& Records Center.

Pan Am, see Pan American World Airways.

Pan American World Airways. 1969. Engineering Drawing entitled, "ETL Flow Bay Drain Extension," Drawing No. J6-SK:JA-381. Mercury, NV: Bechtel Nevada Archives \& Records Center.

Miller, M.G. 1984. Nevada Test Site, Area 25, Radiological Survey and Cleanup Project, 1974-1983 (A Revised Final Report), DOE/NV/10327--5 (Revision 1).

NAEG, see Nevada Applied Ecology Group. 
Nevada Applied Ecology Group. 1976. Studies of Environmental Plutonium and Other

Transuranics in Desert Ecosystems, NVO--159. Prepared for the U.S. Energy Research and Development Administration. Las Vegas, Nevada.

Nevada Applied Ecology Group. 1977. Environmental Plutonium on the Nevada Test Site and Environs, NVO--171. Prepared for the U.S. Energy Research and Development Administration. Las Vegas, Nevada.

Paragon Analytics, Inc. 1997. Laboratory Quality Assurance Plan, Rev. 3. Fort Collins, Colorado.

Perrin, Louis E., U.S. Energy Research and Development Administration. 1977. Letter to Mahlon E. Gates, Manager Nevada Operations Office, regarding a review of Area 25 and BREN Tower. Las Vegas, Nevada.

REECo, see Reynolds Electrical \& Engineering Company, Inc.

Reynolds Electrical \& Engineering Company, Inc. 1993. Radioactive Material Shipping Record, dated August 10. Mercury, NV.

Reynolds Electrical \& Engineering Company, Inc. 1995. Preliminary Characterization of Abandoned Septic Tank Systems. Las Vegas, NV.

Rosenberry, C. 1999. Personal communication to Dustin Wilson, SAIC, regarding operations at Building 3124, 15 January. Las Vegas, NV.

Shotten, M. 1998. Bechtel Nevada. Personal communication to Dave Dahl, IT Corporation, regarding activities at the ETL/TTF, 12 February. Las Vegas, NV.

SNPO, see Space Nuclear Propulsion Office.

Space Nuclear Propulsion Office. 1970. NRDS Master Plan 1969-1970, Nuclear Rocket Development Station, Jackass Flats, Nevada. Las Vegas, NV: U.S. Atomic Energy Commission.

U.S. Department of Energy. 1988a. Environmental Survey Preliminary Report, Nevada Test Site, Nevada, DOE/EH/OEV--15P. Washington, DC: Environment, Safety and Health, Office of Environmental Audit.

U.S. Department of Energy. 1988b. Site Characterization Plan, Yucca Mountain Site, Nevada, DOE/RW--0199, Vols. I-IX. Las Vegas, NV.

U.S. Department of Energy, Nevada Operations Office. 1982. The Radioecology of Transuranics and Other Radionuclides in Desert Ecosystems, NVO--224. Las Vegas, Nevada. 
U.S. Department of Energy, Nevada Operations Office. 1985. The Dynamic of Transuranics and Other Radionuclides in Natural Environments, NVO--272. Las Vegas, Nevada.

U.S. Department of Energy, Nevada Operations Office. 1994. Project Management Plan, Rev. 0. Las Vegas, NV.

U.S. Department of Energy, Nevada Operations Office. 1996. Industrial Sites Quality Assurance Project Plan, Nevada Test Site, Nevada, DOE/NV--372. Las Vegas, NV.

U.S. Department of Energy, Nevada Operations Office. 1998a. Corrective Action Decision Document for CAU 427: Area 3 Septic Waste Systems 2 and 6, Tonopah Test Range, Nevada, Rev. 0, DOE/NV--509. Las Vegas, NV.

U.S. Department of Energy, Nevada Operations Office. 1998b. Corrective Action Investigation Plan for Corrective Action Unit 261: Test Cell A Leachfield System, Nevada Test Site, Nevada, Rev. 0, DOE/NV--519. Las Vegas, NV.

U.S. Department of Energy, Nevada Operations Office. 1998c. Environmental Restoration Project Health and Safety Plan, Rev. 3. Las Vegas, NV.

U.S. Department of Energy, Nevada Operations Office. 1998d. Work Plan for Leachfield Corrective Action Units: Nevada Test Site and Tonopah Test Range, Nevada, DOE/NV--514. Las Vegas, NV. 
Appendix A

\section{Data Quality Objectives Worksheets}




\section{A.1.0 Introduction}

\section{A.1.1 Problem Statement}

Potentially hazardous wastes were discharged to the Area 25 Building 3124 Leachfield System (CAU 266). CAU 266 consists of a single CAS, namely CAS 25-05-09. Existing information about the nature and extent of contamination is insufficient to evaluate and select the preferred corrective action for this site.

This CAU will be investigated based on DQOs developed by representatives of NDEP and DOE/NV. This investigation will determine if COPCs are present and if concentrations exceed regulatory levels in soils surrounding the leachfield and associated collection system. If COPCs are detected, the lateral and vertical extent of contamination will be delineated. Data adequate to close the site under NDEP, RCRA, and DOE requirements will be collected.

\section{A.1.2 DQO Kickoff Meeting}

Table A.1-1 lists the participants present at the FFACO-required DQO Kickoff Meeting and any subsequent meetings that may be required prior to submittal of the CAIP. The goal of the DQO process is to establish the quantity and quality of environmental data required to support corrective action decisions for the CAUs. The process ensures that the information collected will provide sufficient and reliable information to identify, evaluate, and technically defend the chosen corrective action. Unless otherwise required by the results of this DQO and stated in the CAIP, this investigation will adhere to the Industrial Sites QAPP (DOE/NV, 1996b). 
Table A.1-1

DQO Kickoff Meeting Participants

\begin{tabular}{|c|c|c|}
\hline \multirow{2}{*}{ Participant } & \multirow{2}{*}{ Affiliation } & Meeting Date \\
\hline & & $\begin{array}{c}\text { Scoping Meeting } \\
\text { August 20, } 1998\end{array}$ \\
\hline Steve Adams & IT & $x$ \\
\hline Clayton Barrow & DOE & $X$ \\
\hline Rob Boehlecke & SAIC & $x$ \\
\hline Jerry Bonn & $\mathrm{BN}$ & $\mathrm{X}$ \\
\hline Mark DiStefano & IT & $x$ \\
\hline Marjorie England & SAIC & $\mathrm{X}$ \\
\hline Grant Evenson & SAIC & $x$ \\
\hline Syl Hersh & IT & $x$ \\
\hline Mike McKinnon & NDEP & $x$ \\
\hline Jason Moore & SAIC & $x$ \\
\hline Angela Olson & $\mathrm{BN}$ & $x$ \\
\hline Greg Raab & NDEP & $x$ \\
\hline Dan Tobiason & $\mathrm{BN}$ & $x$ \\
\hline Mary Todd & SAIC & $x$ \\
\hline Jeanne Wightman & Mactec & $x$ \\
\hline
\end{tabular}

IT - IT Corporation

SAIC - Science Applications International Corporation

BN - Bechtel Nevada 


\section{A.2.0 Conceptual Model}

The conceptual site model describes the most probable scenario for current conditions at CAU 266. The presence of COPCs within soils is the result of releases from the following known or potential contaminant sources:

- Discharges from designated floor drains within the source building through collection system lines and into possible drainages or outfalls. This occurred at locations when lines did not terminate into the leachfield during certain periods of operation. With an intact and interconnected (complete) collection system, the discharges reached the in-line septic tank and were subsequently dispersed through the leachfield.

- Possible leakage from collection system lines leading to leachfield distribution system

- Possible leakage from the leachfield distribution box

- Possible leakage from the septic tank

- Potential for contaminants dispersed by the leachfield itself

A conceptual model for the CAU 266 Leachfield is provided in Table A.2-1. 


\section{Table A.2-1 \\ Conceptual Model for the CAU 266 Leachfield System \\ (Page 1 of 2)}

\begin{tabular}{|c|c|c|}
\hline $\begin{array}{l}\text { Conceptual Model } \\
\text { Element }\end{array}$ & Assumptions & Source \\
\hline \multirow{6}{*}{ System dynamics } & $\begin{array}{l}\text { Infiltration and concentration of contaminants in the form } \\
\text { of liquid waste into the soil directly below (surrounding) } \\
\text { the leachlines and within the leachfield has occurred. }\end{array}$ & $\begin{array}{l}\text { Knowledge of similar } \\
\text { sites }\end{array}$ \\
\hline & $\begin{array}{l}\text { Minor lateral migration (due to soil anisotropy) of } \\
\text { contaminants in the form of liquid waste into the soil } \\
\text { exists. }\end{array}$ & $\begin{array}{l}\text { Knowledge of similar } \\
\text { sites }\end{array}$ \\
\hline & $\begin{array}{l}\text { Infiltration is limited to less than } 7.6 \mathrm{~m}(25 \mathrm{ft}) \text { vertically } \\
\text { and } 4.5 \mathrm{~m} \text { ( } 15 \mathrm{ft}) \text { horizontally from piping and known } \\
\text { leachfield boundaries. Underground lines extending out } \\
\text { of the area could extend the lateral migration pathways } \\
\text { further and discovery of this would violate the conceptual } \\
\text { model. }\end{array}$ & $\begin{array}{l}\text { Knowledge of similar } \\
\text { sites }\end{array}$ \\
\hline & $\begin{array}{l}\text { Groundwater contamination is unlikely because } \\
\text { environmental conditions at the site; such as an arid } \\
\text { climate and low permeabilities, and depth to groundwater } \\
\text { at approximately } 950 \mathrm{ft} \text {, are not conducive to downward } \\
\text { migration. }\end{array}$ & $\begin{array}{l}\text { Knowledge of similar } \\
\text { sites }\end{array}$ \\
\hline & $\begin{array}{l}\text { No driving forces other than limited precipitation and } \\
\text { infiltration. Also, fluid inputs through the pipings have not } \\
\text { occurred since cessation of operations. Floor drains } \\
\text { within Building } 3124 \text { have reportedly been grouted shut } \\
\text { before } 1993 \text {. }\end{array}$ & $\begin{array}{l}\text { Knowledge of similar } \\
\text { sites }\end{array}$ \\
\hline & $\begin{array}{l}\text { Potential soil contamination along collection lines due to } \\
\text { loss of integrity may exist. }\end{array}$ & $\begin{array}{l}\text { Knowledge of similar } \\
\text { sites }\end{array}$ \\
\hline Source location & $\begin{array}{l}\text { The potentially contributing drains from within the } \\
\text { Building } 3124 \text { source rooms are clearly defined. The } \\
\text { physical components of the collection system drains and } \\
\text { locations of the piping and leachfield, are assumed based } \\
\text { on engineering drawings. The septic tank and } \\
\text { distribution box lid can be physically located (evident } \\
\text { surface expressions) at the ground surface in the field. }\end{array}$ & $\begin{array}{l}\text { Archival engineering } \\
\text { drawings and } 1998 \text { site } \\
\text { visits }\end{array}$ \\
\hline
\end{tabular}




\section{Table A.2-1 \\ Conceptual Model for the CAU 266 Leachfield System}

(Page 2 of 2)

\begin{tabular}{|c|c|c|}
\hline $\begin{array}{c}\text { Conceptual Model } \\
\text { Element }\end{array}$ & Assumptions & Source \\
\hline & $\begin{array}{l}\text { Subsurface effects limited by relatively low contaminant } \\
\text { concentrations and volume and/or low mobility of } \\
\text { constituents }\end{array}$ & Process knowledge \\
\hline $\begin{array}{l}\text { Lateral extent of } \\
\text { potential contaminants }\end{array}$ & $\begin{array}{l}\text { The potential lateral migration of contaminants is } \\
\text { unknown, but if migration has occurred, it will likely be } \\
\text { confined to the boundaries as defined in the conceptual } \\
\text { model. Breaches along the collection system also may } \\
\text { have contributed to potential contaminant migration. }\end{array}$ & $\begin{array}{l}\text { CAU } 266 \text { - No } \\
\text { background information } \\
\text { (soil or other sampling) } \\
\text { has been conducted. In } \\
\text { general, breach areas will } \\
\text { be identified and targeted } \\
\text { during the course of the } \\
\text { investigation. }\end{array}$ \\
\hline $\begin{array}{l}\text { Vertical extent of } \\
\text { potential contaminants }\end{array}$ & $\begin{array}{l}\text { The vertical extent of potential contamination is unknown } \\
\text { but likely (if existent) will be confined to the boundaries as } \\
\text { defined in the conceptual model. Vertical extent would } \\
\text { be limited by low contaminant concentrations and } \\
\text { volumes, lack of driving force, relatively low mobility of } \\
\text { COPCs, and typically decreasing permeability with } \\
\text { increasing depth. }\end{array}$ & $\begin{array}{l}\text { See above. In addition, } \\
\text { this is based on } \\
\text { knowledge of similar } \\
\text { sites. }\end{array}$ \\
\hline $\begin{array}{l}\text { Physical and practical } \\
\text { constraints }\end{array}$ & $\begin{array}{l}\text { Nearby utilities and buildings; adverse weather } \\
\text { conditions; restricted access; heavy equipment and } \\
\text { resource availability; health and safety concerns; } \\
\text { approval of the CAIP and Workplan. }\end{array}$ & Site knowledge \\
\hline Future use & See "Source" (adjacent column box). & $\begin{array}{l}\text { Assumptions are defined } \\
\text { in the Final } \\
\text { Environmental Impact } \\
\text { Statement for the Nevada } \\
\text { Test Site and Off-Site } \\
\text { Locations in the State of } \\
\text { Nevada } \\
\text { (DOE/NV, 1996a) }\end{array}$ \\
\hline Potential exposures & $\begin{array}{l}\text { Ingestion of COPCs in the soil due to inadvertent } \\
\text { exposure during excavation }\end{array}$ & Process knowledge \\
\hline
\end{tabular}




\section{A.3.0 Potential Contaminants}

Section 3.0 of the CAIP provides additional information on the COPCs for the Leachfield CAUs, including PALs and QA/QC requirements.

The CAU 266 Leachfield mainly received effluent from typical janitorial operations, sanitary wastewaters, and possibly oils and greases associated with motorized equipment maintenance. Contamination by VOCs, SVOCs, Total RCRA Metals, and Total Petroleum Hydrocarbons as oil/ diesel may be present, but only trace amounts are expected. Soil displaying measurable quantities of gamma activity also may be present, but lab analyses will only be conducted on a limited number (25 percent) of samples. Field screening for alpha, beta, gamma will be conducted. Geotechnical properties will also be evaluated. Bioassessment samples will be collected if TPH field screening exceeds the action level (100 parts per million [ppm]). Table 3-1 of the Leachfield Work Plan identifies the requirements for general COPCs, and the requirements for CAU-specific COPCs will be based on this table. 


\section{A.4.0 Decisions and Inputs}

\section{A.4.1 Decisions}

Decisions to be resolved by the investigation include:

- Determine if COPCs are present at the site.

- Determine the types and concentrations of COPCs at the site.

- Determine if COPC concentrations exceed PALs.

- Determine the extent of COPCs with enough certainty to develop and evaluate a range of potential corrective actions, including closure in place and clean closure.

\section{A.4.2 Inputs and Strategy}

Inputs to the decisions include those elements of information used to support the decisions in addressing the identified problem. Information inputs, existing data, identified data gaps, and brief strategies are discussed in Table A.4-1. A more detailed discussion of investigation strategies is found in Section A.5.0. 
Table A.4-1

Decisions, Inputs, and General Strategies

(Page 1 of 3 )

\begin{tabular}{|c|c|c|c|c|}
\hline Decision & Input & Existing Data & Data Gap & Strategy \\
\hline \multirow[b]{3}{*}{$\begin{array}{l}\text { Are COPCs present } \\
\text { above PALs at site? }\end{array}$} & $\begin{array}{l}\text { Potential contaminant } \\
\text { identification }\end{array}$ & $\begin{array}{l}\text { Process knowledge of } \\
\text { potential discharges }\end{array}$ & Exact COPCs & $\begin{array}{l}\text { Collect and analyze samples } \\
\text { for COPCs }\end{array}$ \\
\hline & $\begin{array}{l}\text { Potential contaminant } \\
\text { concentration }\end{array}$ & $\begin{array}{l}\text { No sampling data available for } \\
\text { CAU } 266 \text {. }\end{array}$ & $\begin{array}{l}\text { COPC concentrations; do } \\
\text { concentrations exceed PALs? }\end{array}$ & $\begin{array}{l}\text { Collect field screening and } \\
\text { laboratory samples at biased } \\
\text { locations that represent worst } \\
\text { case for contamination; } \\
\text { compare results to field } \\
\text { screening levels or to PALs }\end{array}$ \\
\hline & $\begin{array}{l}\text { Potential contaminant } \\
\text { distribution }\end{array}$ & $\begin{array}{l}\text { Locations of the leachfield and } \\
\text { associated components are } \\
\text { known or generally known } \\
\text { with some degree of certainty; } \\
\text { vertical and lateral extent } \\
\text { limited by small } \\
\text { concentrations and volumes, } \\
\text { lack of driving force, mobility } \\
\text { of COPCs }\end{array}$ & $\begin{array}{l}\text { Exact vertical and lateral } \\
\text { extent }\end{array}$ & $\begin{array}{l}\text { Trench to locate leachfields } \\
\text { and associated components } \\
\text { as needed; collect trenched } \\
\text { samples; drill where needed to } \\
\text { establish worst case depth or } \\
\text { lateral extent of COPCs; if } \\
\text { COPCs are detected, drill } \\
\text { stepout borings to determine } \\
\text { lateral extent and collect } \\
\text { laboratory samples to confirm } \\
\text { extent }\end{array}$ \\
\hline \multirow{3}{*}{$\begin{array}{l}\text { Are potential } \\
\text { contaminants } \\
\text { migrating? }\end{array}$} & $\begin{array}{l}\text { Relative mobility of potential } \\
\text { contaminant }\end{array}$ & $\begin{array}{l}\text { Heavy metals relatively low } \\
\text { mobility; TPH volume limited; } \\
\text { limited migration at similar } \\
\text { sites }\end{array}$ & \multirow[t]{2}{*}{ As discussed above } & \multirow[t]{2}{*}{ As discussed above } \\
\hline & $\begin{array}{l}\text { Potential contaminant } \\
\text { distribution }\end{array}$ & $\begin{array}{l}\text { Limited by contaminant- } \\
\text { specific, geological, } \\
\text { operational, and } \\
\text { meteorological characteristics }\end{array}$ & & \\
\hline & Meteorologic data & $\begin{array}{l}\text { Data on annual precipitation, } \\
\text { evapotranspiration, and } \\
\text { weather }\end{array}$ & None identified & $\begin{array}{l}\text { No specific meteorological } \\
\text { data collection anticipated; } \\
\text { weather and wind speed and } \\
\text { direction noted on daily field } \\
\text { notes }\end{array}$ \\
\hline
\end{tabular}


Table A.4-1

Decisions, Inputs, and General Strategies

(Page 2 of 3 )

\begin{tabular}{|c|c|c|c|c|}
\hline Decision & Input & Existing Data & Data Gap & Strategy \\
\hline \multirow{3}{*}{$\begin{array}{l}\text { Are potential } \\
\text { contaminants } \\
\text { migrating? }\end{array}$} & Geologic/hydrologic data & $\begin{array}{l}\text { General geologic/hydrologic } \\
\text { characteristics of site; specific } \\
\text { geologic conditions of nearby } \\
\text { sites (i.e., Building } 650 \\
\text { Leachfield) }\end{array}$ & $\begin{array}{l}\text { Existence and characteristics } \\
\text { of differing permeability zones }\end{array}$ & $\begin{array}{l}\text { Field log all core by qualified } \\
\text { geologist; collect and analyze } \\
\text { geotechnical samples }\end{array}$ \\
\hline & Biological degradation factors & $\begin{array}{l}\text { Potential hydrocarbons } \\
\text { release in CAU } 266\end{array}$ & $\begin{array}{l}\text { Presence of biomass; } \\
\text { biological parameters to } \\
\text { evaluate natural biological } \\
\text { process }\end{array}$ & $\begin{array}{l}\text { Collect microbial samples } \\
\text { from hydrocarbon sites for } \\
\text { analysis of biological } \\
\text { parameters if TPH is detected } \\
\text { above } 100 \text { ppm via field } \\
\text { screening }\end{array}$ \\
\hline & Radioactive decay & $\begin{array}{l}\text { Low probability of } \\
\text { radionuclides at CAU } 266\end{array}$ & $\begin{array}{l}\text { Presence and type of } \\
\text { radionuclides at Test Cell A }\end{array}$ & $\begin{array}{l}\text { Establish background; field } \\
\text { screen for alpha/beta radiation } \\
\text { using Electra instruments; } \\
\text { collect samples for gamma } \\
\text { spectroscopy at a frequency } \\
\text { of } 25 \% \text { and where field } \\
\text { screening results exceed } \\
\text { action levels }\end{array}$ \\
\hline
\end{tabular}


Table A.4-1

Decisions, Inputs, and General Strategies

(Page 3 of 3)

\begin{tabular}{|c|c|c|c|c|}
\hline Decision & Input & Existing Data & Data Gap & Strategy \\
\hline \multirow{4}{*}{$\begin{array}{l}\text { Data sufficient to } \\
\text { support closure } \\
\text { options? }\end{array}$} & No further action & $\begin{array}{l}\text { Historical evidence that } \\
\text { COPCs released to the } \\
\text { environment; assume no } \\
\text { actions }\end{array}$ & $\begin{array}{l}\text { Presence, concentration, and } \\
\text { extent of COPCs }\end{array}$ & $\begin{array}{l}\text { Insufficient evidence to } \\
\text { proceed without investigation. } \\
\text { Collect field and laboratory } \\
\text { samples; compare results to } \\
\text { PALs. If no COPCs above } \\
\text { PALs, prepare Corrective } \\
\text { Action Decision Document } \\
\text { (CADD)/Closure Report }\end{array}$ \\
\hline & Closure in place & $\begin{array}{l}\text { Potential for TPH and RCRA } \\
\text { constituents; assume } \\
\text { industrial Preliminary } \\
\text { Remediation Goals (PRGs) } \\
\text { per Nevada Administrative } \\
\text { Code (NAC) 445A; assume } \\
\text { use restrictions with signs and } \\
\text { fencing as needed }\end{array}$ & $\begin{array}{l}\text { Presence of regulated } \\
\text { COPCs; concentrations above } \\
\text { PALs }\end{array}$ & $\begin{array}{l}\text { Collect field and laboratory } \\
\text { samples; compare results to } \\
\text { PALs. If no COPCs above } \\
\text { PALs, prepare CADD/Closure } \\
\text { Report; otherwise prepare } \\
\text { CADD }\end{array}$ \\
\hline & In situ bioremediation & $\begin{array}{l}\text { No documented } \\
\text { concentrations in CAU 266; } \\
\text { assume } 100 \text { ppm PAL per } \\
\text { NAC 445A }\end{array}$ & $\begin{array}{l}\text { Presence, concentration, and } \\
\text { extent of COPCs; } \\
\text { biodegradation parameters }\end{array}$ & $\begin{array}{l}\text { Collect field and laboratory } \\
\text { samples; compare results to } \\
\text { PALs. If no COPCs above } \\
\text { PALs, prepare CADD/Closure } \\
\text { Report; otherwise prepare } \\
\text { CADD }\end{array}$ \\
\hline & $\begin{array}{l}\text { Clean closure by contaminant } \\
\text { removal }\end{array}$ & $\begin{array}{l}\text { Potential for TPH and RCRA } \\
\text { constituents; assume } \\
\text { industrial PRGs per NAC } \\
\text { 445A }\end{array}$ & $\begin{array}{l}\text { Presence, concentration, and } \\
\text { extent of COPCs; volume of } \\
\text { contaminated material above } \\
\text { PALs }\end{array}$ & $\begin{array}{l}\text { Collect field and laboratory } \\
\text { samples; compare results to } \\
\text { PALs. If no COPCs above } \\
\text { PALs, prepare CADD/Closure } \\
\text { Report; otherwise prepare } \\
\text { CADD }\end{array}$ \\
\hline
\end{tabular}




\section{A.5.0 Investigation Strategy}

Biased sampling will be conducted during the field investigation to confirm or refute the conceptual model for the site to assess the migration of the COPCs, and to determine if COPCs are present in concentrations exceeding the PALs for the site.

Sampling points will be selected within the leachfield, at both ends of the septic tank, and at the distribution box. Soil surrounding piping showing obvious breaches, leakages, and loss of system integrity will be targeted as additional sampling points. These breaches will be identified with a pipeline video camera (mole) that can be introduced through the piping.

At both the proximal and distal ends of the leachfields, trenches will be cut to transect actual distribution lines and inspect the contents of individual leachfields. These transect locations will be positioned at field-established coordinates (based on engineering drawings) of the leachfield. Subsurface soil samples will be collected at various depths below the distribution lines.

Regions exceeding the field screening levels/PALs would require horizontal stepout or deeper borings to investigate any potential migration of subsurface contaminants.

Field screening of soil for volatile organic concentrations, total petroleum hydrocarbons, and radiological constituents will be conducted during the investigation.

In general, the contents of the leachfields and the surrounding media (soil intervals) will be investigated to a maximum depth (as defined in the primary model) of $7.6 \mathrm{~m}(25 \mathrm{ft}$ ) and two consecutive intervals below appropriate screening levels as determined by field screening and other analytical methods.

Soil samples will be collected primarily by means of a backhoe; and if stepouts or greater depth borings are required, Geoprobe ${ }^{\circledR}$, and/or hollow stem auger drill rig will be used. 


\section{A.5.1 CAU 266}

Investigate the leachfield using a staged approach as generally described in the Leachfield CAU Work Plan. There are no deviations or additional areas of concern from the basic sampling design. At least one bioassessment sample will be collected from each leachfield, distribution box, and ends of the septic tank in CAU 266 if field screening detects TPH. 


\section{A.6.0 Decision Rules}

The following decision rules are applicable to the CAU 266 Leachfield System and will be used to guide the investigation and subsequent data evaluation.

- If, in the course of the investigation, either of the following occur, then the investigation will be halted and rescoped as necessary:

- The conceptual model fails to such a degree that rescoping is required.

- Sufficient data are collected to support evaluation of corrective actions.

- For the subsurface investigation, if field screening indicates no COPCs above fieldscreening action levels, then a sample at the next prescribed subsurface location will be field-screened. If no COPCs are indicated, a confirmatory laboratory sample will be collected, and the subsurface investigation will be halted for that boring.

- For the subsurface investigation, if field screening indicates the presence of COPCs above field-screening levels, then the investigation will continue to determine extent of COPCs until two consecutive samples with field screening results below field screening levels are obtained. Samples will be collected for confirmatory laboratory analysis at the subsurface interval that represents the worst-case, field-screening result and as stated in the previous bulleted item.

- If confirmatory laboratory results indicate the presence of COPCs above PALs, then a Corrective Action Decision Document (CADD) will be prepared.

- If no COPCs are identified above PALs, then a CADD/Closure Report will be prepared according to the outline agreed upon by NDEP and DOE/NV. This type of CADD incorporates the elements of the regular $\mathrm{CADD}$ and the corrective action plan and serves as the Closure Report for the site. 
Table A.6-1

CAU 266 - Specific Decision Points and Rules

(Page 1 of 2)

\begin{tabular}{|c|c|c|c|}
\hline $\begin{array}{l}\text { Investigation } \\
\text { Activity }\end{array}$ & Decision Point & $\begin{array}{l}\text { Decision } \\
\text { Result }\end{array}$ & Decision Rule \\
\hline \multirow{3}{*}{$\begin{array}{l}\text { Pipeline Camera } \\
\text { Survey }\end{array}$} & \multirow{3}{*}{$\begin{array}{l}\text { Can collection system } \\
\text { lines be completely } \\
\text { surveyed (i.e. entire } \\
\text { distance from buildings) } \\
\text { to septic tanks? }\end{array}$} & Yes & $\begin{array}{l}\text { Proceed with subsurface investigation and select soil underlying identified breach } \\
\text { locations as sampling points }\end{array}$ \\
\hline & & $\begin{array}{l}\text { Yes, but } \\
\text { unexpected } \\
\text { tie-ins/ } \\
\text { offshoots are } \\
\text { discovered }\end{array}$ & $\begin{array}{l}\text { Continue to mole new segments; target breaches and possible ends (where they may } \\
\text { terminate) as additional sampling points }\end{array}$ \\
\hline & & No & $\begin{array}{l}\text { 1. Lines have been blocked with residue or contain effluent; suspend mole work but } \\
\text { continue with subsurface investigation; evaluate field data (to include radiological } \\
\text { screening) and collect samples of the pipe contents at a maximum frequency of } 15 \\
\text { linear feet along the blocked section } \\
2 \text {. Lines may have been removed; proceed with subsurface investigation; collect } \\
\text { samples at locations as if the piping was in place and use field screening results to } \\
\text { guide the investigation }\end{array}$ \\
\hline \multirow{3}{*}{$\begin{array}{l}\text { Exploratory } \\
\text { Trenching and } \\
\text { Sample Collection }\end{array}$} & \multirow{3}{*}{$\begin{array}{l}\text { Can tanks, distribution } \\
\text { box/center, and leachfield } \\
\text { distribution lines be } \\
\text { located? }\end{array}$} & Yes & Proceed with subsurface investigation and collect samples at the prescribed locations \\
\hline & & $\begin{array}{l}\text { Yes, but in a } \\
\text { different } \\
\text { location }\end{array}$ & Adjust investigation location \\
\hline & & No & $\begin{array}{l}\text { Lines may have been removed but evidence of leachfield components or other } \\
\text { installations exists; proceed with subsurface investigation; evaluate field data; collect } \\
\text { subsurface samples at frequencies indicated in the Work Plan and at locations as } \\
\text { shown on drawings }\end{array}$ \\
\hline
\end{tabular}


Table A.6-1

CAU 266 - Specific Decision Points and Rules

(Page 2 of 2)

\begin{tabular}{|c|c|c|c|}
\hline $\begin{array}{c}\text { Investigation } \\
\text { Activity }\end{array}$ & Decision Point & $\begin{array}{l}\text { Decision } \\
\text { Result }\end{array}$ & Decision Rule \\
\hline \multirow[b]{2}{*}{$\begin{array}{c}\text { Additional } \\
\text { Subsurface } \\
\text { Investigations: } \\
\text { Begin drilling } \\
5 \text { feet below (and/ } \\
\text { or stepping-out } \\
\text { from) regions } \\
\text { exceeding PALs; } \\
\text { and perform field } \\
\text { screenings at } \\
\text { 5-foot intervals }\end{array}$} & \multirow[b]{2}{*}{$\begin{array}{l}\text { Are field data above field } \\
\text { screening levels? }\end{array}$} & No & Collect confirmatory samples from bottom of boring and end investigation \\
\hline & & Yes & $\begin{array}{l}\text { Begin drilling below trench sample locations to obtain } 2 \text { consecutive samples below field } \\
\text { screening levels; drill step-out borings as needed to define lateral extent of } \\
\text { contamination }\end{array}$ \\
\hline
\end{tabular}




\section{A.7.0 Decision Error}

Biased sampling will be conducted at the CAU 266 system. The sampling strategy targets the worst-case contamination by sampling directly at selected locations, conducting field screening, and sampling individual components of the leachfield and collection system. This will reduce the possibility of missing contamination and yield the highest confidence that the extent of the contamination has been adequately bounded. Two consecutive samples below field screening levels will be obtained from the soil borings to define the lower limit of the affected soils, and these field screening results will be confirmed clean through off-site laboratory analysis. 


\section{A.8.0 References}

DOE, see U.S. Department of Energy.

DOE/NV, see U.S. Department of Energy, Nevada Operations Office.

EPA, see U.S. Environmental Protection Agency.

NAC, see Nevada Administrative Code.

Nevada Administrative Code. 1996. NAC445A.345 - 445A.22755, "Corrective Action Regulations." Carson City, NV: Nevada Division of Environmental Protection.

U.S. Department of Energy. 1992. Environmental Measurements Laboratory Procedures Manual, HASL-300, 27th Edition, Vol. 1. New York, NY.

U.S. Department of Energy, Nevada Operations Office. 1996a. Final Environmental Impact Statement for the Nevada Test Site and Off-Site Locations in the State of Nevada, DOE/EIS 0243. Las Vegas, NV.

U.S. Department of Energy, Nevada Operations Office. 1996b. Industrial Sites Quality Assurance Project Plan, DOE/NV--372. Las Vegas, NV.

U.S. Environmental Protection Agency. 1994. Guidance for the Data Quality Objectives Process, EPA QA/G-4. Washington, DC.

U.S. Environmental Protection Agency. 1996. Test Methods for Evaluating Solid Waste, Physical/Chemical Methods, SW-846, 3rd Edition, CDROM which contains updates for 1986, 1992, 1994, and 1996. Washington, DC. 


\section{Appendix B}

\section{Project Organization}




\section{B.1.0 Project Organization}

The DOE/NV Industrial Sites Project Manager is Janet Appenzeller-Wing and her telephone number is (702) 295-0461.

The names of the project Health and Safety Officer and the Quality Assurance Officer can be found in the appropriate DOE/NV plan. However, personnel are subject to change and it is suggested that the Project Manager be contacted for further information. The Task Manager will be identified in the FFACO Biweekly Activity Report prior to the start of field activities. 


\section{Appendix C}

\section{Building 3124 Equipment Testing Laboratory Floor Plan}

Existing Water \& Sewer Layout, Test Cell "A" Plan 
Figure C-1

\section{Building 3124 Equipment Testing Laboratory Floor Plan}

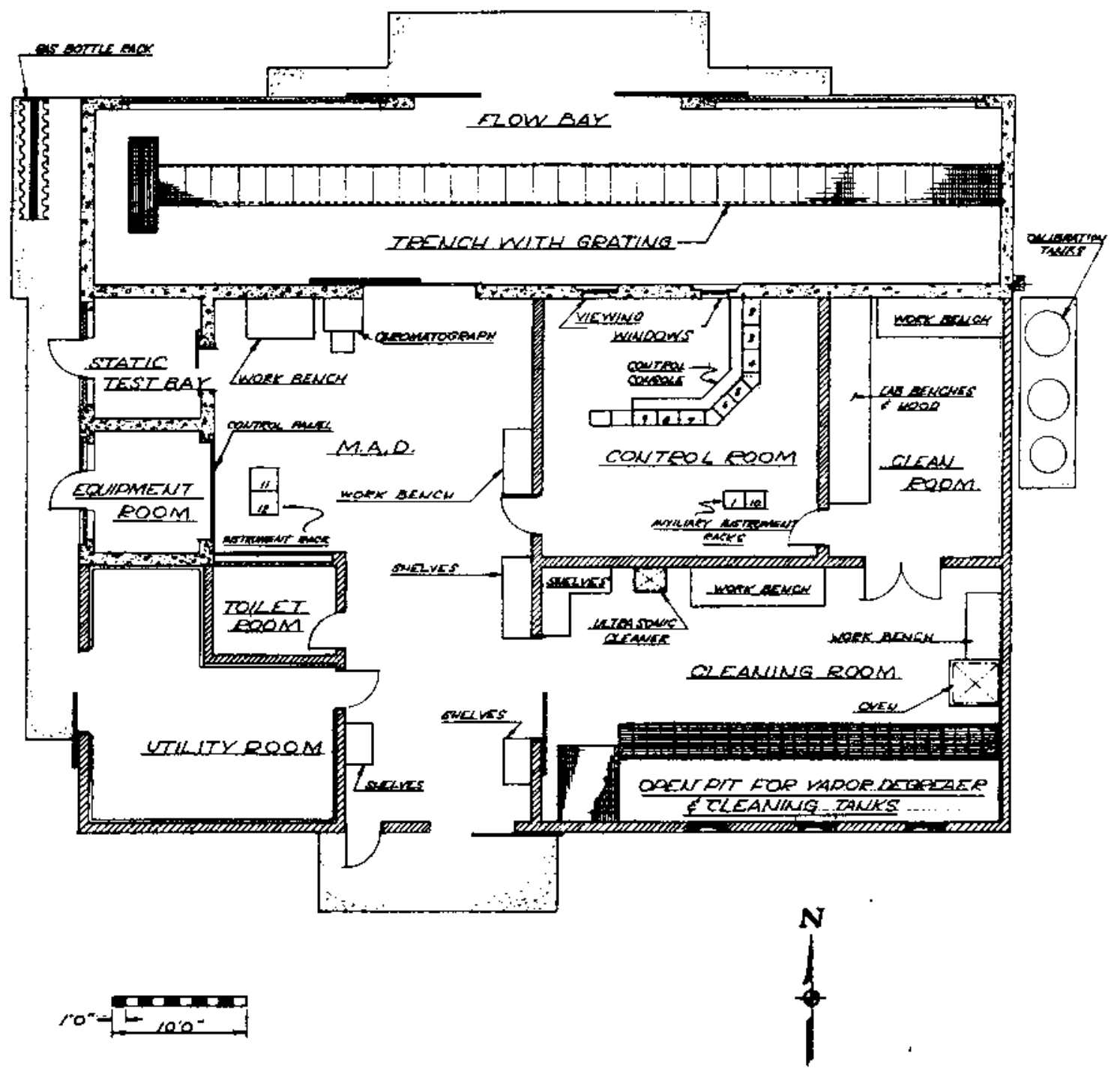




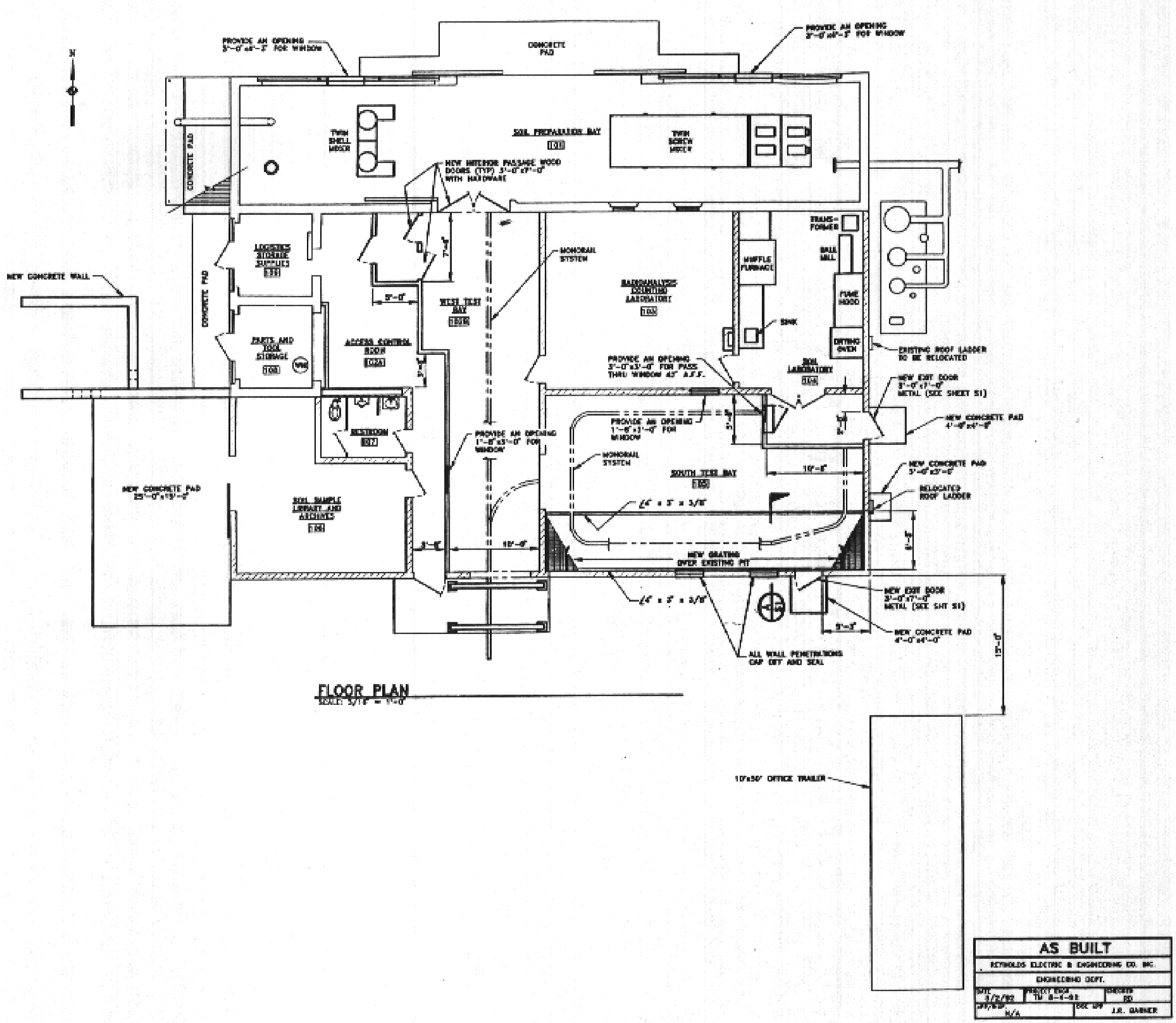

CAU 265 CAIP Revsion: 1

Doon $\mathrm{C}^{-3}$ of $\mathrm{C} 3$

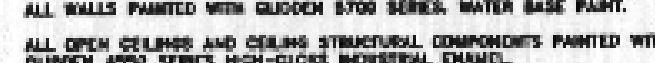

Date: $02 / 23 / 90$
Page C-3 of C-3

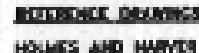

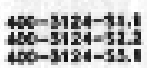
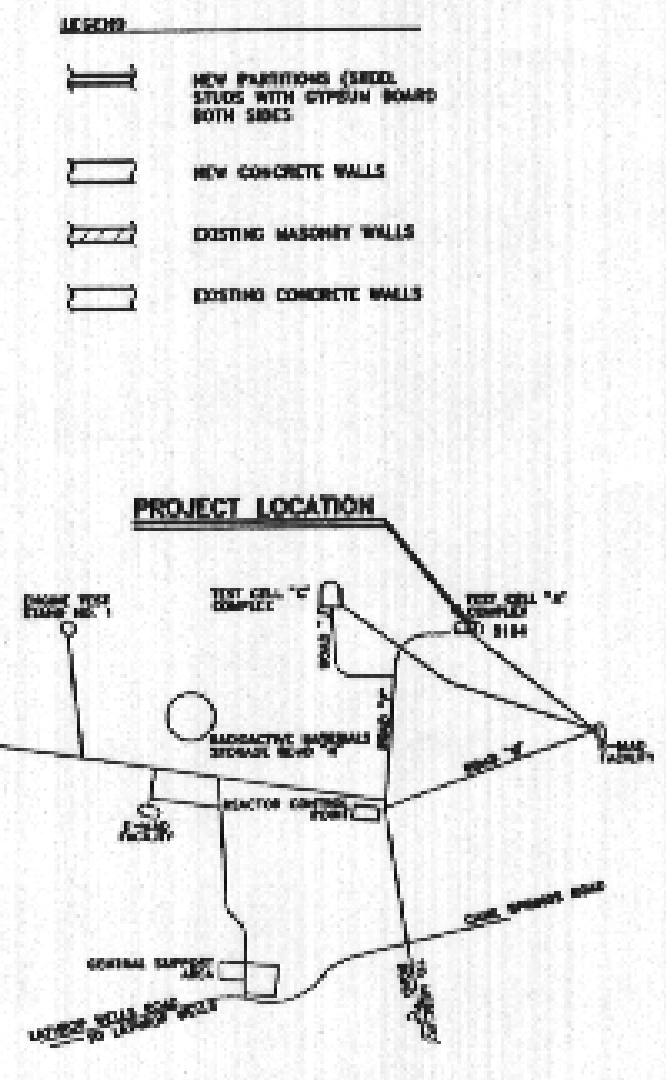

MCINITY MAP

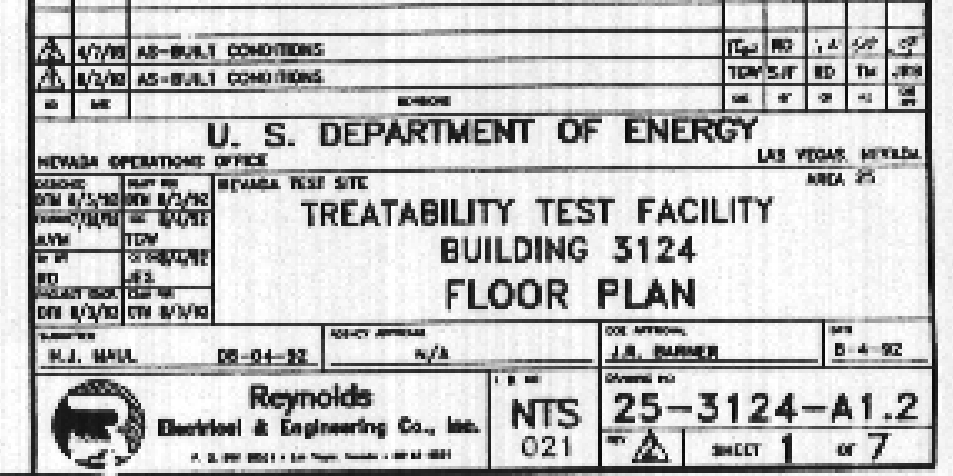




\section{Appendix D}

\section{NDEP Document Review Sheet}




\section{NEVADA ENVIRONMENTAL RESTORATION PROJECT}

DOCUMENT REVIEW SHEET

(Page 1 of 2)

\begin{tabular}{|c|c|c|c|c|c|}
\hline \multicolumn{4}{|c|}{ 1. Document Title/Number: CAIP for CAU 266; Area 25 Building 3124 Leachfield } & \multicolumn{2}{|l|}{ 2. Document Date: October 1998} \\
\hline \multicolumn{4}{|c|}{ 3. Revision Number: Draft } & \multicolumn{2}{|c|}{ 4. Originator/Organization: IT Corporation } \\
\hline \multicolumn{4}{|c|}{ 5. Responsible DOE/NV ERP Project Mgr.: Janet Appenzeller-Wing } & \multicolumn{2}{|l|}{ 6. Date Comments Due: } \\
\hline \multicolumn{6}{|c|}{ 7. Review Criteria: } \\
\hline \multicolumn{3}{|c|}{ 8. Reviewer/Organization/Phone No.: Greg Raab/NDEP/486-2867 } & & \multicolumn{2}{|l|}{ 9. Reviewer's Signature: } \\
\hline $\begin{array}{l}\text { 10. Comment } \\
\text { Number/ } \\
\text { Location }\end{array}$ & 11. Type ${ }^{a}$ & 12. Comment & \multicolumn{2}{|c|}{ 13. Comment Response } & 14. Accept \\
\hline $\begin{array}{l}\text { Page } 9 \text { of } 21 \text {; } \\
\text { second } \\
\text { paragraph, } \\
\text { first sentence }\end{array}$ & & $\begin{array}{l}\text {...of the leachfield Work Plan and described in detail in Appendix A, } \\
\text { Table A.2-1 (Note: underlined portions represent the desired } \\
\text { inserts or additions.) }\end{array}$ & \multicolumn{2}{|l|}{ Comment accepted. } & Yes \\
\hline $\begin{array}{l}\text { On all Figures } \\
\text { with maps }\end{array}$ & & $\begin{array}{l}\text { What is the significance of the inward pointing arrows on the north } \\
\text { arrow symbol? A more traditional north arrow with a compass rose, } \\
\text { might be more appropriate. }\end{array}$ & \multicolumn{2}{|c|}{$\begin{array}{l}\text { Comment noted. This issue will be discussed } \\
\text { programmatically. Future documents will use a simpler } \\
\text { north arrow. }\end{array}$} & $\begin{array}{l}\text { No } \\
\text { changes }\end{array}$ \\
\hline $\begin{array}{l}\text { Back of } \\
\text { Page } 13\end{array}$ & & $\begin{array}{l}\text { The back of Page } 13 \text { is blank. Even though it is opposite a figure, in } \\
\text { other documents this is not the case. Whatever you convention is, } \\
\text { be consistent and follow it. }\end{array}$ & \multicolumn{2}{|c|}{$\begin{array}{l}\text { Comment noted. This is a special circumstance because } \\
\text { the figure is a fold out. In this case, the page must be blank } \\
\text { to accommodate the larger figure. }\end{array}$} & No \\
\hline $\begin{array}{l}\text { Page A-13 } \\
\text { Section A.6.0 } \\
\text { Decision } \\
\text { Rules, first } \\
\text { sentence }\end{array}$ & & $\begin{array}{l}\text { The following decision rules are applicable to the CAU } 266 \\
\text { Leachfield System }\end{array}$ & \multicolumn{2}{|l|}{ Comment accepted. } & Yes \\
\hline
\end{tabular}




\section{NEVADA ENVIRONMENTAL RESTORATION PROJECT}

DOCUMENT REVIEW SHEET

(Page 2 of 2)

\begin{tabular}{|c|c|c|c|c|}
\hline $\begin{array}{l}\text { 10. Comment } \\
\text { Number/ } \\
\text { Location }\end{array}$ & 11. Type ${ }^{a}$ & 12. Comment & 13. Comment Response & 14. Accept \\
\hline General & & $\begin{array}{l}\text { According to the format agreed upon by DOE and NDEP, add } \\
\text { Appendix A2. (or B) Project Organization, which includes: } \\
\text { 1. Name and office telephone of the Project Manager } \\
\text { 2. The following statement, "The identification of the project Health } \\
\text { and Safety Officer and the Quality Assurance Officer can be found } \\
\text { in the appropriate DOE plan. However, personnel are subject to } \\
\text { change and it is suggested that the Project Manager be contacted } \\
\text { for further information. The Task Manager will be identified in the } \\
\text { FFACO Biweekly Activity Report prior to the start of field activities." }\end{array}$ & $\begin{array}{l}\text { Comment accepted. The Leachfield Work Plan contains } \\
\text { Appendix B; this was originally considered applicable to all } \\
\text { the related CAIPs. However, because project management } \\
\text { changes may occur, the information will be included in the } \\
\text { individual CAIPs. }\end{array}$ & Yes \\
\hline
\end{tabular}

a Comment Types: $M=$ Mandatory, $S=$ Suggested

Return Document Review Sheets to DOE/NV Environmental Restoration Division, Attn: QAC, M/S 505. 


\section{Distribution}

*Provide copy in distribution of Rev. 0 and subsequent revisions if applicable. Copies of only the NDEP-approved document will be distributed to the others.

$\underline{\text { Copies }}$

Paul J. Liebendorfer

State of Nevada

Bureau of Federal Facilities

Division of Environmental Protection

333 W. Nye Lane, Room 138

Carson City, NV 89706-0851

Michael McKinnon

State of Nevada

Bureau of Federal Facilities

Division of Environmental Protection

555 E. Washington, Suite 4300

Las Vegas, NV 89101

Sabrina Lawrence

Environmental Restoration Division

DOE/Nevada Operations Office

P.O. Box 98518, M/S 505

Las Vegas, NV 89193-8518

Janet Appenzeller-Wing

Environmental Restoration Division

DOE/Nevada Operations Office

P.O. Box $98518, \mathrm{M} / \mathrm{S} 505$

Las Vegas, NV 89193-8518

Clayton Barrow

Environmental Restoration Division

DOE/Nevada Operations Office

P.O. Box 98518, M/S 505

Las Vegas, NV 89193-8518
2 (Controlled)*

1 (Controlled)*

1 (Controlled)*

1 (Uncontrolled)*

1 (Uncontrolled)* 
Jerry Bonn

Bechtel Nevada

P.O. Box 98521, M/S NTS306

Las Vegas, NV 89193-8521

Steve Nacht

Bechtel Nevada

P.O. Box 98521, M/S NTS306

Las Vegas, NV 89193-8521

Bob McCall

SAIC

P.O. Box 93838

Las Vegas, NV 89193

Mary Todd

SAIC

P.O. Box 93838

Las Vegas, NV 89193

Dustin Wilson

SAIC

P.O. Box 93838

Las Vegas, NV 89193

IT Corporation Central Files

IT Corporation

P.O. Box 93838

Las Vegas, NV 89193

Technical Information Resource Center

DOE/Nevada Operations Office

P.O. Box 98518, M/S 505

Las Vegas, NV 89193-8518

U.S. Department of Energy

Office of Scientific and Technical Information

P.O. Box 62

Oak Ridge, TN 37831
1 (Uncontrolled)*

1 (Uncontrolled)*

1 (Controlled)*

1 (Uncontrolled)*

1 (Uncontrolled)*

1 (Uncontrolled)*

1 (Uncontrolled)

1 (Uncontrolled, electronic copy) 
Manager Southern Nevada FFACO

Public Reading Room

P.O. Box 98521, M/S NLV040

Las Vegas, NV 89193-8521

Manager Northern Nevada FFACO

Public Reading Room

c/o Rosa Silver

IT Corporation

P.O. Box 93838

Las Vegas, NV 89193

FFACO Public Reading Room Coordinator

Rosa Silver

IT Corporation

P.O. Box 93838

Las Vegas, NV 89193
1 (Controlled)

1 (Uncontrolled)

1 (Uncontrolled)

1 (Controlled) 